\title{
Relationships matter: The impact of bank-firm relationships on mergers and acquisitions in Japan
}

\author{
Joseph French $^{\mathrm{a}}$, Juxin Yan ${ }^{\mathrm{b}}$, Yukihiro Yasuda ${ }^{\mathrm{b}}$ \\ ${ }^{\text {a }}$ Monfort College of Business, University of Northern Colorado, Campus Box 128, Greeley \\ Colorado 80639, USA \\ ${ }^{\mathrm{b}}$ Graduate School of Commerce and Management, Hitotsubashi University, 2-1 Naka \\ Kunitachi Tokyo 186-8601, Japan
}

Email: joseph.french@unco.edu, cd142006@g.hit-u.ac.jp, y.yasuda@r.hit-u.ac.jp

\author{
First Draft: March 10
}

This Version: June 14

\begin{abstract}
We dissect the influence of bank-firm relationships on mergers and acquisitions in Japan. Using a comprehensive data set spanning fifteen years, we show that stronger bank-firm relationships generally increase the likelihood and size of M\&A. Contrary to conventional wisdom of the adverse effects of bank-firm relationships in Japan, such as 'zombie lending', our results indicate that Japanese banks facilitate restructuring in the 2000's. However, in cases where a bank plays a dual role as a lender and shareholder to a firm, the likelihood and size of M\&A declines. This result stems from a bank's desire to maintain existing corporate governance mechanisms and control rights.
\end{abstract}

Keywords: Mergers and Acquisitions; Relationship Banking; Japan

JEL classifications: G01; G21; G34 


\section{Introduction}

Does firm structure influence the decision to merge? This question is addressed considerably in extant literature. The current research extends this literature by dissecting the impact of bankfirm relationships on the likelihood and size of mergers and acquisitions (M\&A) in Japan. ${ }^{1}$ Historically the volume of M\&A in Japan has lagged other industrialized nations. However, since the financial reforms of the early 2000's, commonly referred to as the 'Big Bang', the volume of M\&A has increased dramatically (Baker and McKenzie, 2013). While the US and the UK are market-driven economies, Japan is largely a bank-centered economy. A unique aspect of the Japanese economy is the traditionally close ties of Japanese firms with a "main bank'. Japanese firms rely more on bank debt than do firms in the US, and bond financing is only recently becoming important. Furthermore, to mitigate unwelcome takeover threats, Japanese companies frequently link to each other through reciprocal holdings of each other's equity (cross-holding). These unique characteristics of the Japanese banking sector provide an excellent laboratory to understand how various aspects of bank-firm relationships impact M\&A.

More broadly this research fits into the literature on the benefits and costs of relationship banking. Throughout the world, banks are viewed as both healthy and nefarious participants in economic activities. Early research on relationship banking explores agency problems between borrowers and lenders (Leland and Pyle, 1977, Diamond, 1984, and Diamond, 1991). In order to minimize agency costs, banks play the role of monitors and produce private nonfinancial information about their borrowers through monitoring activities. Having privy to private information, banks often work closely with their client firms to improve operational efficiencies and profitability through access to credit via bank lending relationships. These benefits are widely documented in existing literature (Petersen and Rajan, 1995, and Berger and Udell, 1996).

On the other hand, there are potential downsides to close bank-frim relationships. Banks may pursue their own interests at the expense of their clients, examples include tunneling and suboptimal loan portfolio decisions. Sharpe (1990) and Rajan (1992) identify a potential ‘hold-

\footnotetext{
${ }^{1}$ A large exists examining various aspects of M\&A activity in Japan, however the majority of this literature (in English) focuses on sample periods prior to 2006 (i.e. Higgins and Beckman, 2006, Higgins, 2013, and Higgins, 2013)
} 
up' problem that occurs when as a bank's power increases. Private information generated in the course of the lending relationship increases a bank's monopoly power. This may enable a bank to extract rents from the borrower. The potential 'lock-in' problem may be particularly severe if a borrower is very dependent on few banks or in the case of Japan accesses a significant portion of its capital from a 'main bank'.

Given this theoretical background, a large body of empirical literature investigates the implications bank-firm relationships on a variety of corporate financial decisions such as underwriting activities (Puri, 1996), cash holdings (Shikimi, 2015), and firm performance (James, 1987). However, an area that has been relatively overlooked is the impact of bank-firm relationships on the decision to engage in M\&A. M\&A decisions are one of the most important corporate activities, due to the large wealth that is at stake. Additionally, M\&A decisions are often characterized by high levels of information asymmetry between firms. We expect that a bank's role of information providers should be important in these large restructuring actives.

Existent literature examines several aspects of the M\&A decisions including: merger fee structure (Saunders and Srinivasan, 2001), the choice of merger adviser (Allen and Peristiani, 2007), and acquisition outcomes (Dutta and Jog, 2009). However, a limited literature exists on the connection between banking relationships and the M\&A decision itself. In a somewhat related paper, studying M\&A in the United Kingdom, Andriosopoulos and Yang (2015) show that institutional investors increase the likelihood of M\&A to be large and cross-border. However, they do not address the unique bank-firm relationships present in economies like Japan, which allows us to dissect the different aspects of bank-firm relationships on the likelihood, size, and type of M\&A.

We consider how these multifaceted relationships impact M\&A decisions in Japan. Japan is selected as a case study for several reasons. First, Japanese firms disclose their bank relationships and the amount of loans they borrow from each bank, which enables us to measure the bank loan structure of each firm. Furthermore, Japanese banks often hold equity stakes in their client firms. We study how these unique multilayered relationships impact the decision to merge, the type of merger, and the size of merger transactions. In the second phase of our analysis, we investigate the interaction between bank-firm relationships and public financing on merger transactions in a Japanese context. 
To address our empirical research questions, we construct a comprehensive sample of M\&A for the years of 2000-2015. We find that stronger bank-firm relationships generally increase the likelihood and deal size of M\&A in Japan. The impact of bank-firm relationships are not completely straight forward. When a bank is both the largest loan provider and an equity holder in a firm, this dual bank-firm relationship decreases the likelihood and deal size of M\&A. This finding suggests consumption of private benefits for financial institutions when they provide both debt and equity capital. M\&A disrupts existing corporate governance frameworks and our findings suggest that when banks play a dual role within a firm they resist change in the form of M\&A.

In contrast to conventional wisdom of the adverse effects of bank-firm relationships (i.e. zombie lending) our results indicate that Japanese banks facilitate expansion and generally promoted restructuring in the 2000's. However, when the bank is also a sizable equity owner, then this information role is subjugated by the desire to maintain existing corporate governance frameworks, which may permit greater consumption of private benefits. To test the robustness of our findings and to control for potential endogeneity we consider several subsamples of M\&A. The importance of bank-firm relationships remains positive and significant when we restrict bank-firm relationship to be stable (five years or more) or when we consider firms participating in M\&A for the first time. Overall our results demonstrate that nature of bankfirm relationships are important in understanding M\&A.

The remainder of the paper proceeds as follows. Section 2 reviews relevant institutional background, in Section 3 our hypothesis is developed, Section 4 describes our sample and presents our empirical methods, Section 5 discusses the empirical results, and Section 6 provides a summary of observations and directions for further research.

\section{Institutional Background}

Since 1998 corporate restructuring and strategic repositioning by large companies in Japan has accelerated. According to Schaede (2008) diversified firms began to exit businesses, either out of financial necessity or due to a perceived need to be more focused in order to compete in the global market place. Financial and legal reforms made available a variety of new M\&A methods that were previously not possible. This coupled with the change in Japan's shareholder structure away from the previously dominant stable cross-shareholdings has added increased 
incentives for corporations to target increased performance and profitability via M\&A (Nomura, 2006).

The ownership structure of Japanese corporations has dramatically changed in the decade following the financial reforms of the 2000's known as the 'Big Bang'. For example, bank ownership of corporations has declined and foreign ownership has increased. Moreover, the presence of foreign investors in market transactions has grown even more prominent than before. The share of transactions by foreigners in the Tokyo Stock Exchange (TSE) first section surpassed 40\% in 1997, reaching 50\% in 2000 and 60\% in 2006 (Miyajima et al., 2015). However, 2006 marked a temporary peak in foreign ownership as the selloff of bank shareholdings paused and many firms began forming strategic alliances through M\&A. According to Miyajima et al., (2015) foreign ownership declined from $13.9 \%$ to $11.7 \%$ during the financial crisis of 2008 and has remained stable.

Banks throughout the world devote a great deal of attention to developing a loan portfolio. Assessment of borrowers' credit history, ability, and potential success is an important component of a bank's performance (Elyasiani and Goldberg, 2004). Theoretical literature in banking places special emphasis on the type and nature of borrowers as any information asymmetry regarding a bank's client portfolios impacts bank performance. In an early model of bank behavior, Stiglitz and Weiss (1981) show that when banks lend to small firms, the relationship is prone to adverse selection and moral hazard problems due to limited information. Along the same lines, Diamond (1984, 1991) and Leland and Pyle (1977) demonstrate that such adverse selection issues are largely alleviated for big financial institutions who can acquire significant amounts of information on borrowers. In the context of the current paper, we conjecture that Japanese 'main bank' relationships act similar to large financial institutions and alleviate information asymmetries between firms when firms engage in M\&A.

Our sample allows us to analyze the influence of these relationships considering a period of regulatory changes impacting banks analysis of their loan portfolios. Starting in fiscal year 1999, Japanese companies began following a new accounting standard that requires consolidated rather than parent-only earnings in financial reports. Prior to this this reform, it would have harmed a company's reputation to sell off subsidiaries, but this new standard creates incentives to liquidate unprofitable subsidiaries in order to enhance reported earnings. Concurrently, a new fair value standard requires companies to apply market value to their 
financial assets, including their stable cross-holdings. Under fair-value accounting, the difference between the book and market values of stockholdings is categorized in the capital section of the balance sheet. This treatment avoids reporting these losses directly in income. However, the application of fair value accounting has the effect of reducing equity which encourages companies to sell crossholdings which valued below book value. Former Japanese practices valued these assets at book value and this method avoided reporting huge losses incurred during the market decline of the 1990s (Yoost et al., 2001).

This change in the accounting standard creates incentives for companies to sever ties with poorly performing subsidiaries, commonly called 'zombie firms'. The change to fair value accounting encourages Japanese banks to facilitate mergers to reduce the adverse impact of 'zombie's' on their balance sheets.

Figure $1 \mathrm{a}$ and $1 \mathrm{~b}$ plots the annual number and value of M\&A in Japan for our sample period. Prior to the mid-2000's the number and value of M\&A in Japan is relatively low. ${ }^{2}$ However, the number and value of M\&A increases sharply in the mid-2000s for mergers between Japanese (IN_IN) companies and for cross border mergers (IN_OUT). This is partly due to the accounting reforms discussed previously and the subsequent introduction of new company law that clarifies the scope of subsidiaries for parent firms. ${ }^{3}$ Figure $1 \mathrm{~b}$ illustrates that the aggregate value cross-border M\&A in Japan is volatile but generally increasing. Japan's ageing population and growing international competition is the likely culprit for Japanese firms seeking growth through overseas expansion.

\section{[Figures 1a and 1b here]}

\section{Hypothesis Development}

\subsection{Bank-firm relationships and $M \& A$}

There is a lively debate in academic literature on the benefits and costs of banking relationships to firms. On one hand, a bank possesses private information regarding client firms that is

\footnotetext{
${ }^{2}$ Data on M\&A in Japan from 1996-2000 are available upon request. It is noted that the number and size of M\&A between 1996-2000 is significantly lower than after 2000.

${ }^{3}$ The new company law went into effect in 2006.
} 
unavailable to outsiders. This certification benefit arises because banks use a firm's private information accessed during banking relationships to mitigate information asymmetry in a firm's investment activities (Diamond, 1991; Leland, 2007). In Japan (main) banks often hold the first or second largest equity position in their client firms. The dual status of a main bank as a lender and shareholder gives it the role of monitor, thus mitigating the agency problem between the managers and owners (Prowse, 1990).

In the context of the current paper, Ivashina et al. (2009) show that bank-firm relationships impact M\&A decisions. Banks may transmit information about a target to potential acquirers/bidders. Their findings also suggest that banks facilitate mergers to transfer debt from weak to strong clients, consistent with banks' objective to improve the credit quality of their own portfolios. This is likely particularly true in the case of Japanese banks surrounding the accounting rule changes in the early 2000's. The migration to fair value accounting increases the costs of 'zombies' and potentially creates incentives for banks to facilitate mergers to improve their financial statements.

Alternatively, conflicts of interest may enable main banks to extract rents via their ties with firms and hence be agents of the status quo (Besanko and Kanatas, 1993; Rajan, 1992). A number of studies on relationship banking have documented that close ties with a bank adversely impact firm performance (e.g., Weinstein and Yafeh, 1998; Agarwal and Elston, 2001; Wu and $\mathrm{Xu}, 2005$; Peek and Rosengren, 2005). Generally, banks have debt-holder interest, which does not align with stockholder interests. Therefore, conflicts of interest exist between banks and equity holders. Since large wealth is typically at stake during M\&A it is expected that these conflicts of interest will be severe.

In Japan conflicts of interest are likely multidimensional and dependent on the nature of the bank-firm relationships. Indeed, Kang and Liu (2007) show that Japanese banks create conflicts of interest when underwriting corporate bonds. They demonstrate that close prior lending relationships is the primary driver of these conflicts of interest. Therefore, bank ownership may negatively impact the likelihood of merging. This is particularly, likely bank claims are on cash-flows have a dual nature as conflicts of interest are potentially greater. One may expect a negative relationship between the strength of bank relationship and deal size as a bank will be adverse to a merger when more of its resources are invested in the deal 
(Andriosopoulos and Yang, 2015). Additionally, large M\&A can impact corporate governance dynamics of their existing holdings and therefore their control rights could be diluted.

Empirically, we use three proxies for the strength of bank-firm relationships: 1) A dummy variable if a bank is the primary lender and the percentage of a firm's loan from the bank is greater than 10\% (MB_relationship), 2) the primary bank's stock ownership of the firm (MB_ownership), and 3) the primary bank's loans ratio (MB_loan_ratio). We expect a positive relationship between the probability of $M \& A$ and the strength of bank-firm relationships, if banks use mergers to improve their balance sheets and transmit 'soft' information between clients. On the other hand, a negative relationship between M\&A and the strength of firm-bank ties would suggest rent extraction (tunneling) by banks. Indeed, the impact of bank-firm relationships on M\&A could depend on the exact nature of the bank-firm relationships. If banks only have a lending relationships with a firm, then the primary concern of the bank will be for the quality of its loan portfolio. On the other hand, in Japan bank-firm relationships are multifaceted with banks often having both debt and equity claims on client firms. In the cases of these dual relationships maintaining equity control rights may become more critical than incremental improvements in loan portfolios. Therefore, exact nature of bank-firm relationships could have asymmetric impacts on a firm's decision to engage in M\&A.

In light of the above discussion, we formulate our null hypothesis as follows.

\section{H0: Bank-firm relationships are not related to the probability of merging}

\section{Sample and Methodologies}

We collect data on M\&A in Japan from January 2000 to December 2015 from RECOF. RECOF is the most comprehensive and well-known source for data on Japanese M\&A. To be included in our sample acquirers must be listed Japanese companies. We exclude all the deals where the bidders are financial or regulated firms (Harford and Uysal, 2014; Andriosopoulos and Yang, 2015). Following existing literature we apply the following filters: Deals under 100 million Japanese Yen (JPY) are eliminated from the sample, only firms with fiscal years beginning in April are included, companies without complete financial data are excluded, and 
firms with multiple $\mathrm{M} \& \mathrm{~A}$ are coded as having undertaken $\mathrm{M} \& \mathrm{~A} \cdot{ }^{4}$ Our M\&A data are merged with financial data obtained from Astra Manager Database. M\&A deals undertaken by Japanese listed companies provide a final sample of 1453 domestic targets and 663 foreign targets.

To examine the role of bank-firm relationships on M\&A, probit and tobit specifications are employed. ${ }^{5}$ The dependent variable (M\&A) is equal one (size of merger) if the Japanese acquirer merges within the year in probit (tobit) models. Furthermore, we segment our M\&A sample into merger types. In particular, we consider mergers between two Japanese firms (IN_IN), mergers between a listed Japanese firm and a non-Japanese firm (IN_OUT), and mergers between a listed Japanese firm and an unlisted firm (IN_IN_UNLISTED). ${ }^{6}$ Following Petersen (2009), we estimate p-values in both probit and tobit models based on clustering by firm and year to account for correlations among error terms within firm and year. We also add year dummies in the analysis to account for macroeconomic changes within our sample period.

Inspired by prior work on the determinants of M\&A, we incorporate several other control variables in to our empirical models (Harford and Uysal, 2014). The emphasis on bank-firm relationships is based on the theoretical literature on financial intermediation (Rajan 1992), which assumes that banks establish customer relationships with borrowers in order to gather information and that such information are available only to banks that have lent to a firm. In this case, it is unlikely that both incumbent and potential lenders are able to exercise market power and set loan conditions such as interest rates in a similar manner. Therefore, bank-firm relationships play an important role in determining loan conditions.

Harford and Uysal (2014) argue that access to debt markets can also influence M\&A. Specifically, firms that exclusively borrow from private lenders can be rationed by the debt capacity of their lenders. Therefore, constrained access to debt or equity could be negatively related to M\&A activity. Firms that do not have access to the public bond or equity markets face financing constants and hence are more reliant on banking relationships. The lack of access to public debt and equity markets hinders a firm's ability to raise capital on short notice and

\footnotetext{
${ }^{4}$ The majority of Japanese firms' fiscal year begins in April.

${ }^{5}$ Tolbit models are also estimated determine the impact of bank-firm relationships on the size of M\&A.

${ }^{6}$ It should be noted that IN_IN_Unlisted is a subset of IN_IN. 
may reduce the cash component of acquisition offers (Uysal, 2011) or M\&A activity in general. To formally control for these impacts, we control for access to public debt and equity markets by including dummy variables equity to one is a firm has issued bonds (Pub_Bond_5Y) or public equity (SEO_5Y) in the previous five years.

We include the natural logarithm of sales as firms with higher sales are typically positively associated with M\&A. Firms with large cash reserves are shown to be more likely to undertake M\&A. To control for this we include cash holdings as a percentage of total assets (Cash_vs_TA). A company's life cycle is known to impact M\&A, for example firms are more likely to merge in early and late stages of their lifecycle. To control for this impact, we include firm age (Age). Firms that generate high levels of operating profit margin relative to total assets are generally found to be more likely to engage in M\&A. We control for this impact by including EBITDA divided by total assets (EBITDA_TA) in the regressions. To account for the impact of debt on the likelihood to merge we add long-term borrowing (Long_Loans_Ratio) and leverage (Market_Leverage). Previous literature demonstrates the importance of valuation as a determinate of M\&A. To account for these potential investment opportunities, we include the market-to-book ratio (Market_to_Book). To control for industry concentration and firm experience with M\&A, we add the Herfindahl index (Herfindahl_index) and industry M\&A liquidity (Industry_MA_Liquidity) respectively. Panel A of Table 1 contains a detailed description of all the variables used in our analysis.

\section{[Table 1 here]}

Panel B of Table 1 presents the summary statistics. Descriptive statistics are reported separately for the entire sample and for firms that undertake M\&A to allow for comparison between groups. Univariate comparisons between the whole sample and the M\&A sample show little discernable difference in variables relating to bank-firm relationships.

However, several characteristics are significantly different between the two subsamples. Our variable to proxy access to the public debt and equity markets (Pub_Bond_5Y and SEO_5Y) is much higher for firms that engage in M\&A: $38 \%$ vs. $8 \%$ for access to the bond market and $18 \%$ vs. $13 \%$ for firms accessing the seasoned equity market. This result provides preliminary evidence for a positive association between access to capital markets and M\&A. Firm performance (EBITDA_TA, Ln_Sales) and valuation (Market_Book) measures are higher for 
the M\&A subsample offering evidence that better performing and higher valued firms are more likely to undertake M\&A. Consistent with previous studies, firm leverage is lower for firms engaging in $M \& A$ compared to the entire sample. We also note that firm age is slightly higher for M\&A firms (53 years vs. 49 years).

\section{Results}

\subsection{Univariate Results}

To begin understanding the complex relationship between various aspects of bank-firm relations and M\&A decisions we segment our sample and perform t-tests for differences in means. Figure 2 presents a graphical depiction of our sample segmentation. Category 1 contains 433 mergers and represents firms whose main bank is both an equity holder and lender to the firm. Category 2 contains 549 mergers by firms who have a main bank with whom is has only a lending relationship. Finally, category 3 contains 671 merger events for firms who do not have lending or ownership relationships with a main bank.

\section{[Figure 2 and table 2 here]}

Results of t-tests for differences in means between these categories are reported in Table 2 and indicate the multifaceted impact of bank-firm relationships on M\&A. We find that in general main bank ties increase the average propensity to engage in M\&A. This result is consistent among all types of M\&A. However, when we analyze the difference between firms in category 1 and firms in category 2 our univariate results dramatically change. When the bank plays a dual role of lender and shareholder of a firm, then the firm is less likely to undertake M\&A compared to firms whose bank is only a debt provider. These univariate results indicate a potential problem when banks have dual roles within firms. Typically, banks are primarily concerned about their loan portfolios and during the restructuring of the 2000's facilitated M\&A to improve their balance sheets following the Japanese financial reforms. However, our univariate results indicate that when banks are also shareholders in firms to which they lend, then their concern for the quality of their loan portfolios may have been outweighed by a desire to maintain existing corporate governance schemes that facilitate consumption of private benefits or are adverse to diluting events such as M\&A. While the results of these univariate tests shed light on the nuanced impact of bank-firm relationships on M\&A they could be a 
artifact of other factors. We now consider the role of bank-firm relationships formally with probit and tobit analysis.

\subsection{Do bank-firm relationships impact $M \& A$ ?}

Tables $3 \mathrm{a}$ and $3 \mathrm{~b}$ present the results of our multivariate analysis. Several empirical specifications are estimated and results are reported for four subsamples based on merger type. Do bank-firm relationships impact the likelihood to engage in M\&A? Our results indicate the answer to this question is in the affirmative. We find a positive association between MB_Relationship, MB_Stock_Ratio, MB_Loans_Ratio and the probability to engage in M\&A. In all empirical specifications this relationship is positive and statistically significant at the $1 \%$ level. Our results suggest that banks generally transfer 'soft' information between clients and provide a certification benefit that encourages M\&A in the sample period. Furthermore, the change in accounting standards in early to mid-2000's created incentives for banks to reduce ties with poorly performing clients (i.e. 'zombies') to improve their loan portfolios. Our findings indicate this may have triggered increased motivation for banks to encourage M\&A. Our results are not only statistically significant, but also economically important. For example, Table $3 b$ reports the marginal effect of MB_Loans_Ratio on the probability to undertake M\&A. We show that a $1 \%$ increase in MB_Loans_Ratio leads to a 5.8\% increase in the likelihood to engage in M\&A.

The positive association between bank-firm relationships and M\&A is stable across merger types. Coefficients are stable and consistently positive for IN_IN, IN_IN_Unilisted, and IN_OUT (cross border) mergers. These results clarify the general certification role of banks in the facilitation of M\&A in the recent history of Japan. There exists a possibility that bank-firm relationships may increase the probability to merge, but that this phenomenon is only related to large or small mergers. To consider this, question several tobit models are estimated. Results from several empirical specifications are reported in Table $3 \mathrm{~b}$. We use the size of M\&A as the dependent variable along with the previous independent variables. Consistent with our earlier findings, we document a strong positive relationship between the strength of bank-firm relationships and the size of M\&A. Control variables area consistently signed in probit and tobit speculations. Overall, our results clearly point to role of bank-firm relationships in promoting the number and size of M\&A in Japan. It is import to note that these base line results are stable across all merger types. 


\section{[Tables 3a, 3b here]}

Aligned with existing literature on the determinants of M\&A in other countries: access to public capital markets, sales, cash holding, firm age, leverage, market-to-book ratio, M\&A experience, and industry concentration are generally important to predict the probability and size of M\&A. In Tables 3a and 3b the coefficients on Pub_Bond_5Y and SEO_5Y are positive and statistically significant, signifying a strong association between access to capital markets and the likelihood and size of M\&A in Japan. This finding is stable across empirical specifications and merger types. These findings illustrate formally that firms with access to greater amounts of capital tend to increase investment, in this case M\&A.

Sales are found to be positively associated with merger activity as better performing firms are more likely to engage in M\&A (Almazan et al, 2010). Interestingly Cash_vs_TA only appears to be relevant for cross border M\&A demonstrating strong significant positive association in most empirical specifications. Firm age is an important determinant in IN_IN mergers in Japan. As expected younger firms are more likely to engage in M\&A within the Japanese market as consolidation typically is more likely early in a firm's lifecycle. Controlling for other determinants of $\mathrm{M} \& \mathrm{~A}$, we show consist with existing literature that Market_Leverage negatively impacts the probability and size of M\&A as firms with most leverage tend to have lower financing flexibility (Harford et al., 2012 and Uysal, 2011). Valuation impacts the size and probability of M\&A as a firms Market_to_Book ratio increases so does its likelihood to undertake M\&A consistent with the notion that better performing firms are more likely to seek expansion (Harford, 1999). EBITDA_TA is negatively associated with the likelihood of M\&A in Japan in contrast to the findings of Harford and Uysal (2014). This finding is consistent with our hypothesis that during the 2000's banks facilitated M\&A to improve the quality of their balance sheets. Firms that are generating higher levels of operating cash-flow per unit of asset are less likely to engage in M\&A during restructuring periods. M\&A experience (Industry_MA_Liquidity) is strongly positively associated with the probability to merge only for cross-border M\&A. This finding demonstrates that firms in industries with more M\&A experience are more likely to seek international expansion.

\subsection{Dual bank-firm relationships and $M \& A$}


Given the general importance of bank-firm relationships illustrated in the previous section, we now dissect these multidimensional relationships by considering the impact of various components of bank-firm relationships. In particular, we consider the impact of bank-firm relationships when the main bank is also a shareholder or when the largest lender is also a stockholder. Probit and tobit models are estimated with the inclusion of MB_Relationship_Loan_Stock, and MB_Stock_Ratio_Biggest_Lender. Tables 4a and 4b report these results for the probit and tobit specifications respectively. As the tables clearly reveal when a bank plays a dual role within a client firm these relationships reduce the likelihood and size of M\&A. If a firm's primary bank or largest lender is also an equity holder then this significantly reduces the likelihood and size of M\&A for the client firm.

\section{[Tables $4 a$ and $4 b$ here]}

We conjecture this is due to potential agency cost of dual capital providers. While in general banks are concerned about the quality of their loan portfolios and used M\&A for restructuring following the financial reforms of the early 2000's, when the bank also has control rights they are adverse to diluting these control rights with M\&A. Furthermore, there exists a possibility that when banks hold ownership stakes in client firms that certain private benefits are consumed by bank managers given existing corporate governance frameworks. M\&A disrupts existing corporate governance frameworks and hence banks with ownership and lending relationships with client firms may discourage M\&A. It is noted that the majority of control variables are consistent with our previous findings with the exception of variables which proxy access to public capital, which remain positively signed but lose their significance in some merger types.

\section{[Tables 5 here]}

\subsection{Robustness checks: Stable firm-bank relationships and first M\&A}

An important consideration in studies of this type is the potential for endogeneity. For example, the causal relationship uncovered between bank-firm and M\&A could be due to the fact that M\&A facilitates greater bank-firm relationships. Due to the historical nature of bank-firm relationships in Japan this is unlikely the case. However, we formally investigate this possibility by including a variable to proxy the stability of bank-firm relationships. Table 5a and $5 \mathrm{~b}$ includes the results of our regressions with the inclusion of MB_Relationship_5Y which 
is a dummy variable equal to one if a firm is in a main bank relationship for at least five years. Table 5a contains the results for firms with a main bank relationship and Table $5 \mathrm{~b}$ contains the results for firms whose main banks have both debt and equity claims. Our results show that the significance of main bank relationship on the probability to merge remains positive and statistically significant in all merger types. Furthermore, signs on control variables remain consistently signed and stable with earlier results.

\section{[Tables 5a and 5b]}

As an additional robustness check on our finding of banks facilitating M\&A, we segment our sample into firms who experienced M\&A for the first time. We then proceed to test the determinants of M\&A for this sub-sample. Table 6 reports the results of this exercise. Once again the importance of bank-firm relationships remains positive and significant in all cases. Consistent with earlier results we find that bank relationships are positive for this sub-sample of firms and alleviate endogeneity concerns. For firms experiencing M\&A for the first time we find that age is only associated with cross-border M\&A in contrast with our full sample results.

\section{[Tables 6]}

\section{Discussion and future research}

We show that firm structure matters for M\&A decisions. In particular, we uncover a positive association between bank-firm relationships and the decision to engage in M\&A in Japan. Our results suggest that Japanese bank transfer nonfinancial information between client firms providing a certification benefit, which facilitates M\&A. The financial reform in the early and mid-2000's put incentives in place for banks to sever ties with poorly performing clients (zombies). Following these reforms M\&A activity in Japan increased. Our results suggest that banks used M\&A to improve their balance sheets and reduce 'zombie' lending. In contrast to conventional wisdom of the adverse effects of bank-firm relationships (i.e. zombie lending) our results indicate that Japanese banks facilitate expansion and promoted client firm restructuring in the 2000's. However, a battery of additional tests demonstrate that the relationship between $M \& A$ and bank-firm relationships are more intricate. 
When we segment firms into those which have banks who are both lenders and shareholders the impact of bank-firm relationships on M\&A changes. We demonstrate that when a bank is also an equity holder of a firm this reduces the likelihood and size of M\&A. When banks have dual claims to a firm's cash-flows existing corporate governance mechanisms are paramount to incentives to improve loan portfolios. In market based economies, banks generally only have a debt claims, which provides incentives for them to take actions to improve the quality of their loan portfolios. In general, after the financial reforms of the early 2000's our results indicate that Japanese banks used M\&A to eliminate zombie lending and improve loan portfolios. In the Japanese system, banks often have a dual claim on cash-flows as both lenders and equity holders. Our results show that when this is the case bank prefer to maintain existing corporate governance systems or prevent dilution of control rights, which reduces the likelihood and size of M\&A. Overall, our results clearly establish that bank-firm relationships impact M\&A. Furthermore, by considering the multiple facets of bank-firm relationships in Japan we show it's not just relationships that matter, but the type of relationship.

A potential fruitful avenue for further research is to explore previous status as a 'zombie' firm as a determinant of M\&A. While the relationship with a main bank reduces the cost of financial distress in the short run, it may also increase moral hazard and hurt firms in the long run (Wu and $\mathrm{Xu}, 2005)$. Zombie firms are almost guaranteed financing by their main banks during times of distress. This implies that banks may continue to provide financial assistance to firms whose financial condition would otherwise warrant bankruptcy or restructuring. It would be interesting to see if mergers act as a sort of 'zombie' killer.

A second potential extension of the current work is to look at bank entrenchment within client firms (Chernobai, and Yasuda, 2013). In Japan, business groups (keiretsu) are not familycontrolled. They are historically manager-dominated inter-corporate groups. Morck and Nakamura (2005) assert that these business groups provide a vehicle for management entrenchment. Managers of the most influential banks within the keiretsu are in a position to transfer wealth from weaker members of the business group. Moreover, the promise of assistance if the firm should experience financial distress as well as the threat of withholding such assistance could prompt weaker firms to permit tunneling. Therefore, we would expect that where incentives are higher for consumption of private benefits mergers are less likely to merge (Dow and McGuire, 2009). 


\section{Acknowledgements}

Yasuda and Yan greatly appreciate the financial support from Mizuho Securities. Yasuda greatly appreciates the financial support of the Grant-in-Aid for Scientific Research (C) (No. 25380407) from MEXT. 


\section{References}

Agarwal, R., and Elston, J., 2001. Bank-firm relationships, financing and firm performance in Germany, Economics Letters 72 (2), 225-232.

Allen, L., Peristiani, S., 2007. Loan underpricing and the provision of merger advisory services. Journal of Banking \& Finance, 31(12), 3539-3562.

Andriosopoulos, D., Yang, S., (2014). The impact of institutional investors on mergers \& acquisitions in the United Kingdom, Journal of Banking \& Finance, doi:

http://dx.doi.org/10.1016/j.jbankfin. 2014.06.004

Berger, A. N., Udell, G.F., 1996. Universal banking and the future of small business lending. Working paper.

Besanko, D., Kanatas, G., 1993. Credit market equilibrium with bank monitoring and moral hazard. Review of Financial Studies 6 (1), 213-232.

Baker \& McKenzie, 2013. Asia Pacific Guide to Merger \& Acquisitions, http://www.bakermckenzie.com/files/Uploads/Documents/MA_Guide_.pdf

Byrd, J., Hickman, K., 1992. Do outside directors monitor managers? Evidence from tender offer bids. Journal of Financial Economics 32, 195-221.

Caballero, R., J., Hoshi, T., Kashyap. A., K., 2008. Zombie lending and depressed restructuring in Japan. American Economic Review 98(5), 1943-77.

Campello, M., Graham, J., Harvey, C., 2010. The real effects of financial constraints: Evidence from a financial crisis. Journal of Financial Economics 97, 470-487

Chernobai, A., Yasuda, Y., 2013. Disclosures of material weaknesses by Japanese firms after the passage of the 2006 Financial Instruments and Exchange Law, Journal of Banking \& Finance 37 (5), 1524-1542.

Clark, K., Ofek, E., 1994. Mergers as a means of restructuring distressed firms: An empirical investigation. The Journal of Financial and Quantitative Analysis 29(4), 541-565.

Diamond, D. W., 1991. Monitoring and reputation: The choice between bank loans and directly placed debt. Journal of Political Economy 99(4), 689-721.

Dow, S., McGuire, J., 2009. Propping and tunneling: Empirical evidence from Japanese keiretsu, Journal of Banking \& Finance 33 (10), 1817-1828.

Drucker, S., Puri, M., 2007. Banks in capital markets: a survey. In: Eckbo, B.E. (Ed.), Handbook in Corporate Finance: Empirical Corporate Finance. Elsevier/North-Holland, Amsterdam, pp. 189-227.

Dutta, S., Jog, V., 2009. The long-term performance of acquiring firms: A re-examination 
of an anomaly. Journal of Banking \& Finance, 33(8), 1400-1412.

Elyasiani, E., Goldberg, G., 2004. Relationship lending: a survey of the literature. Journal of Economics and Business 56 (4), 315-330.

Fukuda, S.-I., Nakamura, J.-I., 2011. Why did 'zombie' firms recover in Japan? World Economy 34, 1124-1137.

Harford, J., Humphery-Jenner, M., Powell, R., 2012. The sources of value destruction in acquisitions by entrenched managers. Journal of Financial Economics 106(2), 247-261.

Harford, J., Uysal, V. B., 2014. Bond market access and investment, Journal of Financial Economics 112 (2), 147-163.

Higgins, H., Beckman, J., 2006. Abnormal returns of Japanese acquisition bidders -impact of pro-M\&A legislation in the 1990s. Pacific-Basin Finance Journal 14 (3), 250-268.

Higgins, H., 2013. Conflicts of interest between banks and firms: Evidence from Japanese mergers, Pacific-Basin Finance Journal 24 (3), 156-178

Higgins, H., 2013. Do stock-for-stock merger acquirers manage earnings? Evidence from Japan, J. Account. Public Policy 32, 44-70

Ivashina, V., Nair, V., Saunders, A., Massoud, N., Stover, R., 2009. Bank debt and corporate governance. Review of Financial Studies 22 (1), 41-77.

Ivashina, V., Scharfstein, D., 2010. Bank lending during the financial crisis of 2008. Journal of Financial Economics 97(3), 319-338.

Hoshi, T., Kashyap, A. K., 2004. Japan's financial crisis and economic stagnation. Journal of Economic Perspectives 18(1), 3-26.

James., C., 1987. Some evidence on the uniqueness of bank loans. Journal of Financial Economics 19(2), 217-235.

Kang, J., Liu, W., 2007. Is universal banking justified? Evidence from bank underwriting of corporate bonds in Japan. Journal of Financial Economics 87 (1), 142-186.

Leland, H., Pyle, D. H., 1977. Informational asymmetries, financial structure, and financial intermediation, Journal of Finance 32 (2), 371-387.

Leland, H. E., 2007. Financial synergies and the optimal scope of the firm: Implications for mergers, spinoffs, and structured finance. The Journal of Finance 62, 765-807.

Mehran, H., Stulz, R.M., 2007. The economics of conflicts of interest in financial institutions. Journal of Financial Economics 85 (2), 267-296.

Miyajima, H., Hoda, T., Ogawa, R., 2015. Does ownership really matter? The role of foreign investors in corporate governance in Japan, RIETI discussion paper series 15-E-078. 
Miyajima, H., Kuroki. F., 2007. The Unwinding of Cross-Shareholding in Japan: Causes, Effects, and Implications. In: Aoki, M., G. Jackson and H. Miyajima (eds.) Corporate Governance in Japan: Institutional Change and Organizational Diversity, Oxford University Press, pp. 79-124.

Morck, R., Nakamura, M., 2005. A frog in a well knows nothing of the ocean: A history of corporate governance in Japan. In: Morck, R. (Ed.), A History of Corporate Governance Around the World: Family Business Groups to Professional Managers. University of Chicago Press, Chicago.

Nomura, 2006. Trends in Japanese Company Related M\&As in 2005. Nomura Securities Co., Ltd., Investment Banking Research Dept., Tokyo

Peek, J., Rosengren, E., 2005. Unnatural selection: Perverse incentives and the misallocation of credit in Japan. American Economic Review 95, 4, 1144-1166.

Petersen, M.A., Rajan, R. G., 1994. The benefits of lending relationships: Evidence from small business data. The Journal of Finance 49(1),3-37.

Prowse, S.D., 1990. Institutional investment patterns and corporate financial behavior in the United States and Japan. Journal of Financial Economics 27 (1), 43-66.

Puri, M., 1996. Commercial banks in investment banking conflict of interest or certification role? Journal of Financial Economics 40(3), 373-401.

Rajan, R.G., 1992. Insiders and outsiders: the choice between informed and arms' length debt. Journal of Finance 47 (4), 1367-1400.

Schaede, U., 2008. Choose and Focus: Japanese Business Strategies for the 21st Century. 1st ed. Cornell University Press. http://www.jstor.org/stable/10.7591/j.ctt7zfbt.

Sharpe, S.A., 1990. Asymmetric information, bank lending, and implicit contracts: A stylized model of customer relationships. The Journal of Finance 45(4), 1069-1087.

Shikimi, M., 2015. Bank relationships and cash holdings: Evidence from emerging firms in Japan. SSRN working paper.

Stiglitz, J., Weiss, A., 1981. Credit rationing in markets with imperfect information. American Economic Review 71 (3), 393-410.

Uysal, V. B., 2011. Deviation from the target capital structure and acquisition choices. Journal of Financial Economics, 102 (3), 602-620.

Weinstein, D.E., Yafeh, Y., 1998. On the costs of a bank-centered financial system: evidence from the changing main bank relations in Japan. Journal of Finance 53 (2), 635-672. 
$\mathrm{Wu}, \mathrm{X} ., \mathrm{Xu}, \mathrm{L} . \mathrm{L} ., 2$ 2005. The value information of financing decisions and corporate governance during and after the Japanese deregulation. The Journal of Business 78(1), 243280.

Yoost, D., Tagai, T., Zencak, A., 2001. Japan paves the way for more M\&A. International Tax Review 12, 13-18. 


\section{Figures and Tables}

Figure 1A: Number of M\&A in Japan from 2000-2015

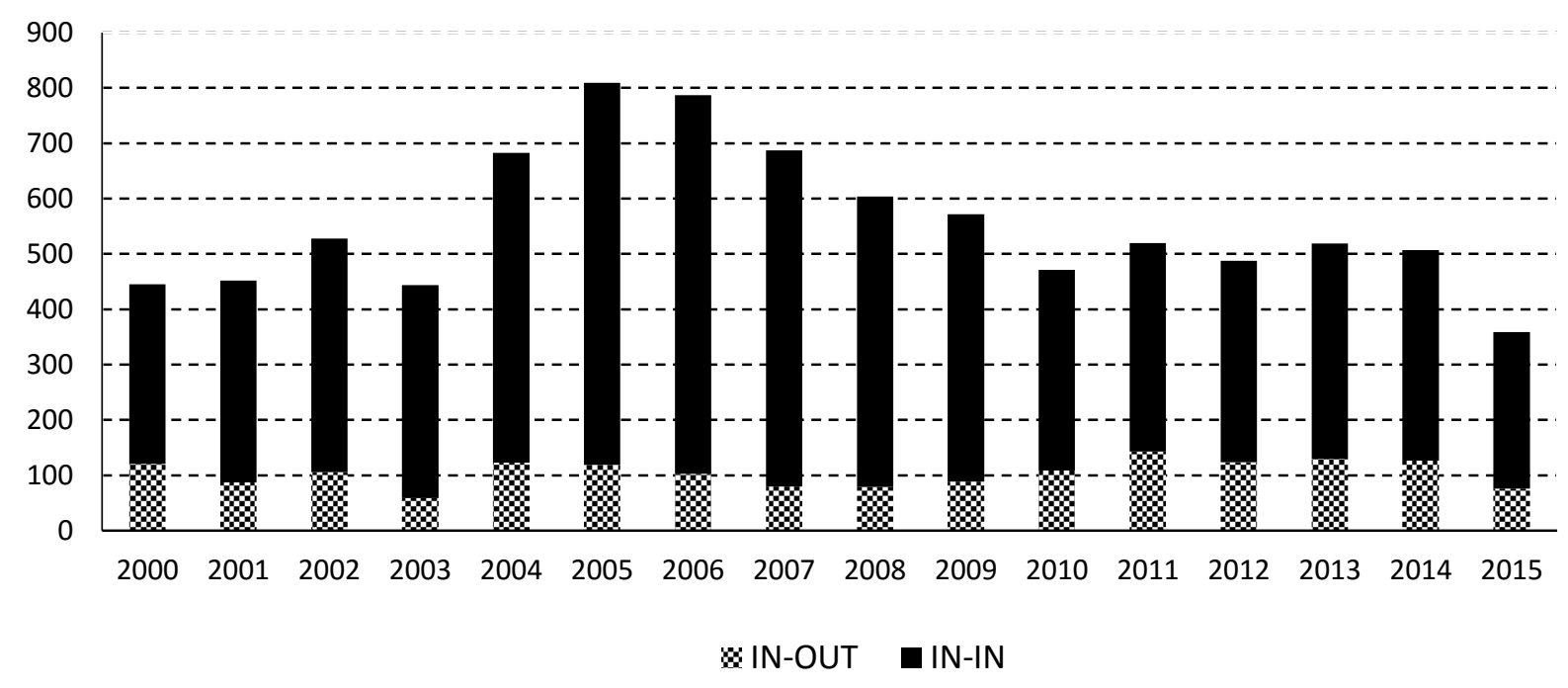

Figure 1B: Aggregate value of M\&A in billions of Japanese Yen (JPY)

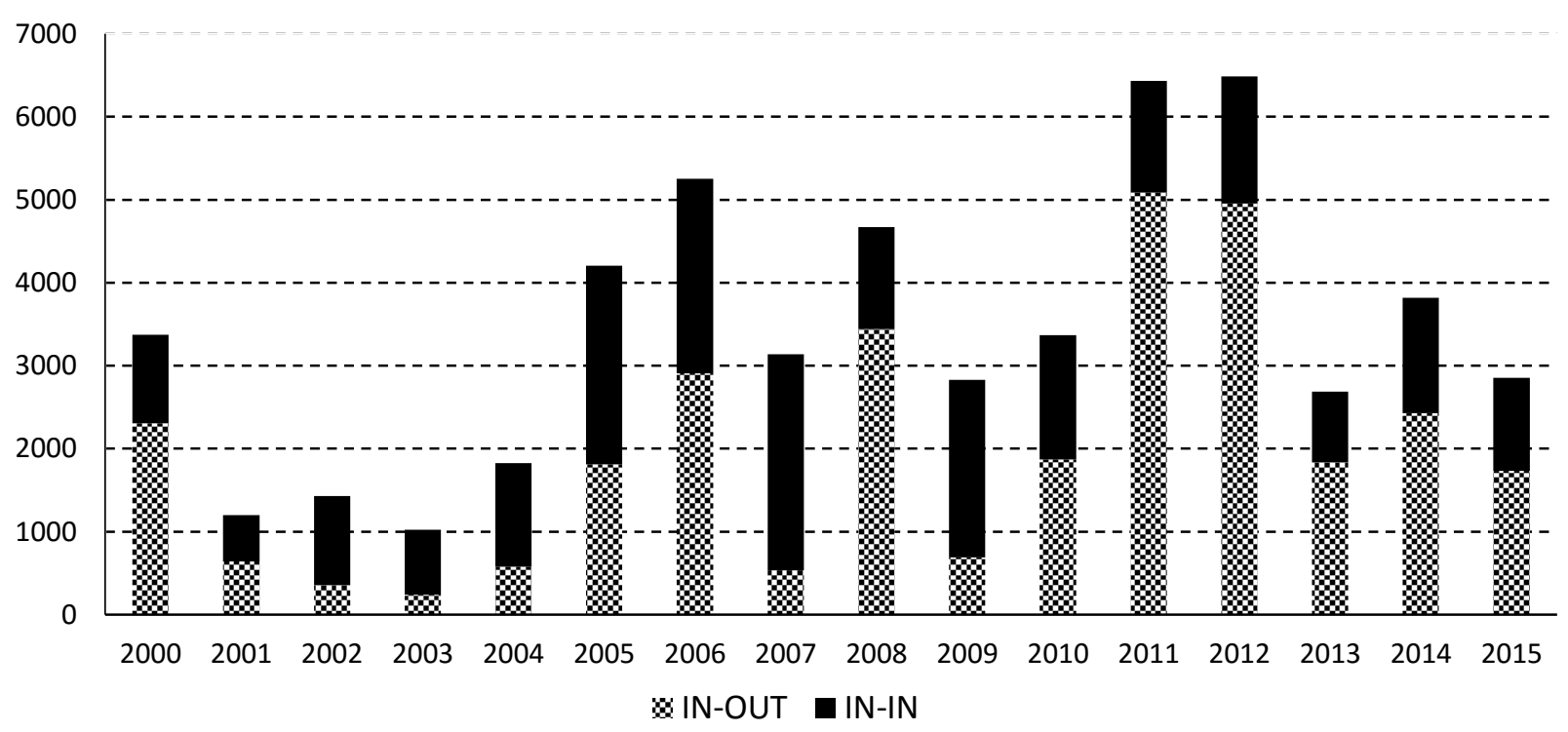




\section{Figure 2: Segmentation of M\&A sample}

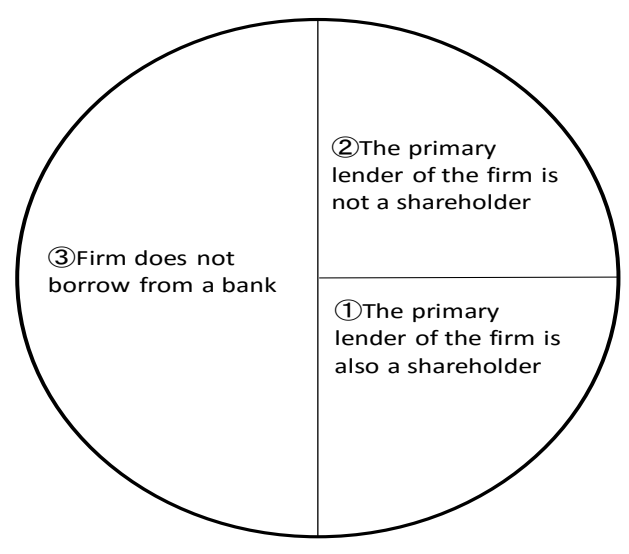

Table 1: Variable Definitions and Descriptive Statistics

\begin{tabular}{|c|c|}
\hline Mnemonics & Descriptions \\
\hline \multicolumn{2}{|l|}{ Pane/ A. M\&A variables } \\
\hline MA & Dummy variable equal to one if a listed Japanese firm acquirer merges and the size of the M\&A is greater than 100 million yen. \\
\hline MA_IN_IN_Listed & Dummy variable equal to one if a listed Japanese firm mergers with a listed Japanese firm and the size of the M\&A is greater than 100 million yen \\
\hline MA_IN_IN_Unlisted & Dummy variable equal to one if a listed Japanese firm mergers with an unlisted Japanese firm and the size of the M\&A is greater than 100 million yen \\
\hline MA_IN_OUT & Dummy variable equal to one if a listed Japanese firm mergers with a non-Japanese firm and the size of the M\&A is greater than 100 million yen \\
\hline MA_Size & M\&A size over the book value of total assets \\
\hline MA_Size_IN_OUT & M\&A size over the book value of total assets when a listed Japanese firm mergers with a non-Japanese firm \\
\hline MA_Size_IN_IN_listed & M\&A size over the book value of total assets when a listed Japanese firm mergers with a listed Japanese firm \\
\hline MA_Size_IN_IN_Unlisted & M\&A size over the book value of total assets when a listed Japanese firm mergers with an unlisted Japanese firm \\
\hline \multicolumn{2}{|c|}{ Panel B. Bank firm repationship variables } \\
\hline MB_Relationship & Dummy variable equal to one if a bank is the primary lender \\
\hline MB_Loan_Ratio & Primary bank's borrowing by the firm divided by total assets \\
\hline MB_Stock_Ratio & Bank's stock owhership if it is the within the top 10 owners and the top owners among banks \\
\hline MB_Relationship_Loan_Stock & Dummy variable equal to one if primary bank's stock owhership is within the top 10 owners \\
\hline MB_Stock_Ratio_Biggest_Lender & Primary bank's stock ownership of the firm \\
\hline Pub_Bond_5Y & Dummy variable equal to one if a firm has accessed to the public bond market in the past five years \\
\hline SEO_5Y & Dummy variable equal to one if a firm has conducted seasoned equity offering in the past five years \\
\hline Long_Loans_Ratio & Long-term borrowing by the firm divided by total assets \\
\hline \multicolumn{2}{|l|}{ Panel CFirm-specific charateristics } \\
\hline In_Sales & Natural logarithm of sales \\
\hline Cash_vs_TA & Cash and cash equivalents held by firms divided by total assets \\
\hline Age & Firm age (years from the foundation) \\
\hline Market_Leverge & Book value of debt over Market value of equity plus book value of debt \\
\hline Market_to_Book & Market value over the book value of total assets \\
\hline EBITDA_TA & Operating income before depreciation divided by total assets \\
\hline Industry_MA_Liquidity & Sum of M\&A value for each year and industry divided by total assets of all firms in the same industry and year \\
\hline Herfindahl_Index & Sum of the squares of the market shares of all firms sharing the same industry code \\
\hline Occurred & Dummy variable equal to one if a listed Japanese firm acquirer merges \\
\hline IN_OUT_Occurred & Dummy variable equal to one if a listed Japanese firm mergers with a non-Japanese firm \\
\hline IN_IN_Listed_Occurred & Dummy variable equal to one if a listed Japanese firm mergers with a listed Japanese firm \\
\hline IN_IN_Unlisted_Occurred & Dummy variable equal to one if a listed Japanese firm mergers with an unlisted Japanese firm \\
\hline Size & M\&A size over the book value of total assets \\
\hline IN_OUT_Size & M\&A size over the book value of total assets when a listed Japanese firm mergers with a non-Japanese firm \\
\hline IN_IN_Listed_Size & M\&A size over the book value of total assets when a listed Japanese firm mergers with a listed Japanese firm \\
\hline IN_IN_Unlisted_Size & M\&A size over the book value of total assets when a listed Japanese firm mergers with an unlised Japanese firm \\
\hline
\end{tabular}




\begin{tabular}{|c|c|c|c|c|c|c|c|c|c|c|c|c|c|c|}
\hline \multirow[b]{2}{*}{ Variables } & \multicolumn{7}{|c|}{ Whole sample } & \multicolumn{7}{|c|}{ M\&A sample } \\
\hline & Mean & Std. Dev & $\min$ & $10 p$ & Median & $90 p$ & $\max$ & Mean & Std. Dev & $\min$ & $10 p$ & Median & $90 p$ & $\max$ \\
\hline$\overline{\mathrm{MA}}$ & 0.08 & 0.28 & 0 & 0 & 0 & 0 & 1 & 1 & 0 & 1 & 1 & 1 & 1 & 1 \\
\hline MA_IN_IN_listed & 0.03 & 0.16 & 0 & 0 & 0 & 0 & 1 & 0.31 & 0.46 & 0 & 0 & 0 & 1 & 1 \\
\hline MA_IN_IN_Unlisted & 0.05 & 0.21 & 0 & 0 & 0 & 0 & 1 & 0.56 & 0.5 & 0 & 0 & 1 & 1 & 1 \\
\hline MA_IN_OUT & 0.02 & 0.15 & 0 & 0 & 0 & 0 & 1 & 0.29 & 0.45 & 0 & 0 & 0 & 1 & 1 \\
\hline MA_Size & 0.01 & 0.09 & 0 & 0 & 0 & 0 & 11.26 & 0.07 & 0.31 & 0 & 0 & 0.01 & 0.14 & 11.26 \\
\hline MA_Size_IN_IN_Listed & 0 & 0.05 & 0 & 0 & 0 & 0 & 8.14 & 0.02 & 0.18 & 0 & 0 & 0 & 0.02 & 8.14 \\
\hline MA_Size_IN_IN_Unlisted & 0 & 0.04 & 0 & 0 & 0 & 0 & 3.55 & 0.03 & 0.14 & 0 & 0 & 0 & 0.06 & 3.55 \\
\hline MA_Size_IN_OUT & 0 & 0.06 & 0 & 0 & 0 & 0 & 11.26 & 0.02 & 0.21 & 0 & 0 & 0 & 0.02 & 11.26 \\
\hline MB_Relathionship & 0.59 & 0.49 & 0 & 0 & 1 & 1 & 1 & 0.63 & 0.48 & 0 & 0 & 1 & 1 & 1 \\
\hline MB_Loan_Ratio & 4.16 & 7.31 & 0 & 0 & 1.48 & 11.38 & 457.89 & 2.99 & 5.46 & 0 & 0 & 1.13 & 8.08 & 119.25 \\
\hline MB_Stock_Ratio & 2.17 & 2.21 & 0 & 0 & 2.06 & 4.88 & 43.87 & 2.17 & 2.13 & 0 & 0 & 2.13 & 4.79 & 34.73 \\
\hline MB_Relationship_Loan_Stock & 0.37 & 0.48 & 0 & 0 & 0 & 1 & 1 & 0.32 & 0.47 & 0 & 0 & 0 & 1 & 1 \\
\hline MB_Stock_Ratio_Biggest_Lender & 1.31 & 2.02 & 0 & 0 & 0 & 4.66 & 43.87 & 1.1 & 1.84 & 0 & 0 & 0 & 4.28 & 29.6 \\
\hline Long_Loans_Ratio & 0.08 & 0.1 & 0 & 0 & 0.04 & 0.21 & 2.19 & 0.08 & 0.09 & 0 & 0 & 0.04 & 0.2 & 0.85 \\
\hline Pub_Bond_5Y & 0.08 & 0.27 & 0 & 0 & 0 & 0 & 1 & 0.25 & 0.43 & 0 & 0 & 0 & 1 & 1 \\
\hline SEO_5Y & 0.13 & 0.34 & 0 & 0 & 0 & 1 & 1 & 0.22 & 0.41 & 0 & 0 & 0 & 1 & 1 \\
\hline In_Sales & 10.52 & 1.62 & 2.77 & 8.62 & 10.38 & 12.64 & 17.12 & 11.71 & 2.1 & 5.33 & 9.05 & 11.7 & 14.43 & 17.12 \\
\hline Cash_vs_TA & 0.15 & 0.12 & -0.03 & 0.04 & 0.12 & 0.3 & 0.98 & 0.15 & 0.13 & 0 & 0.04 & 0.12 & 0.32 & 0.95 \\
\hline Age & 52.06 & 22.52 & -1 & 20 & 54 & 81 & 133 & 49.96 & 26.45 & -1 & 13 & 53 & 85 & 129 \\
\hline Market_Leverge & 0.56 & 0.24 & 0 & 0.21 & 0.58 & 0.86 & 1 & 0.48 & 0.24 & 0 & 0.14 & 0.49 & 0.79 & 0.98 \\
\hline Market_to_Book & 1.16 & 1.92 & 0.2 & 0.69 & 0.97 & 1.6 & 339.2 & 1.56 & 5.84 & 0.28 & 0.79 & 1.08 & 2.05 & 339.2 \\
\hline EBITDA_TA & 0.04 & 0.1 & -6.36 & -0.02 & 0.04 & 0.1 & 0.59 & 0.05 & 0.09 & -1.45 & 0.01 & 0.05 & 0.12 & 0.55 \\
\hline Industry_MA_Liquidity & 0.01 & 0.02 & 0 & 0 & 0 & 0.01 & 1.38 & 0.01 & 0.02 & 0 & 0 & 0 & 0.02 & 0.37 \\
\hline Herfindahl_Index & 0.08 & 0.06 & 0.02 & 0.03 & 0.06 & 0.14 & 1 & 0.08 & 0.06 & 0.02 & 0.03 & 0.06 & 0.16 & 1 \\
\hline
\end{tabular}

Notes: The table presents the summary statistics of dependent and explanatory variables based on the whole sample and M\&A subsample. The M\&A sample comprises 3,618 M\&A deals undertaken by Japanese public bidders from Jan 1, 2000 to Dec 31, 2015. The industry classification is based on TOPIX Sector Indices. All variables are defined in Panel A of Table 1.

Table 2: Univariate Results on firm-bank relationships and M\&A

\begin{tabular}{|c|c|c|c|c|}
\hline & occured & IN_IN_Listed_occured & IN_IN_Unlist_occured & IN_OUT_occured \\
\hline MB_Relathionship & $0.01[5.14]^{* * *}$ & $0.01[3.72]^{* * *}$ & $0.01[2.77]^{* * *}$ & $0.01[3.81]^{* * *}$ \\
\hline MB_Relationship_Loan_Stock & $-0.04[-11.57]^{* *}$ & $-0.02[-7.13]^{* * *}$ & $-0.03[-9.66]^{* * *}$ & $-0.02[-7.42]^{* * *}$ \\
\hline
\end{tabular}

Notes: The table above presents the results of a t-test for differences in average propensity to undertake M\&A based on the segmentations presented in figure 2. All variables are defined in Panel A of Table 1. ***, **, * Represent significance at $1 \%, 5 \%$, and $10 \%$ respectively. 
Table 3A: Probit Results

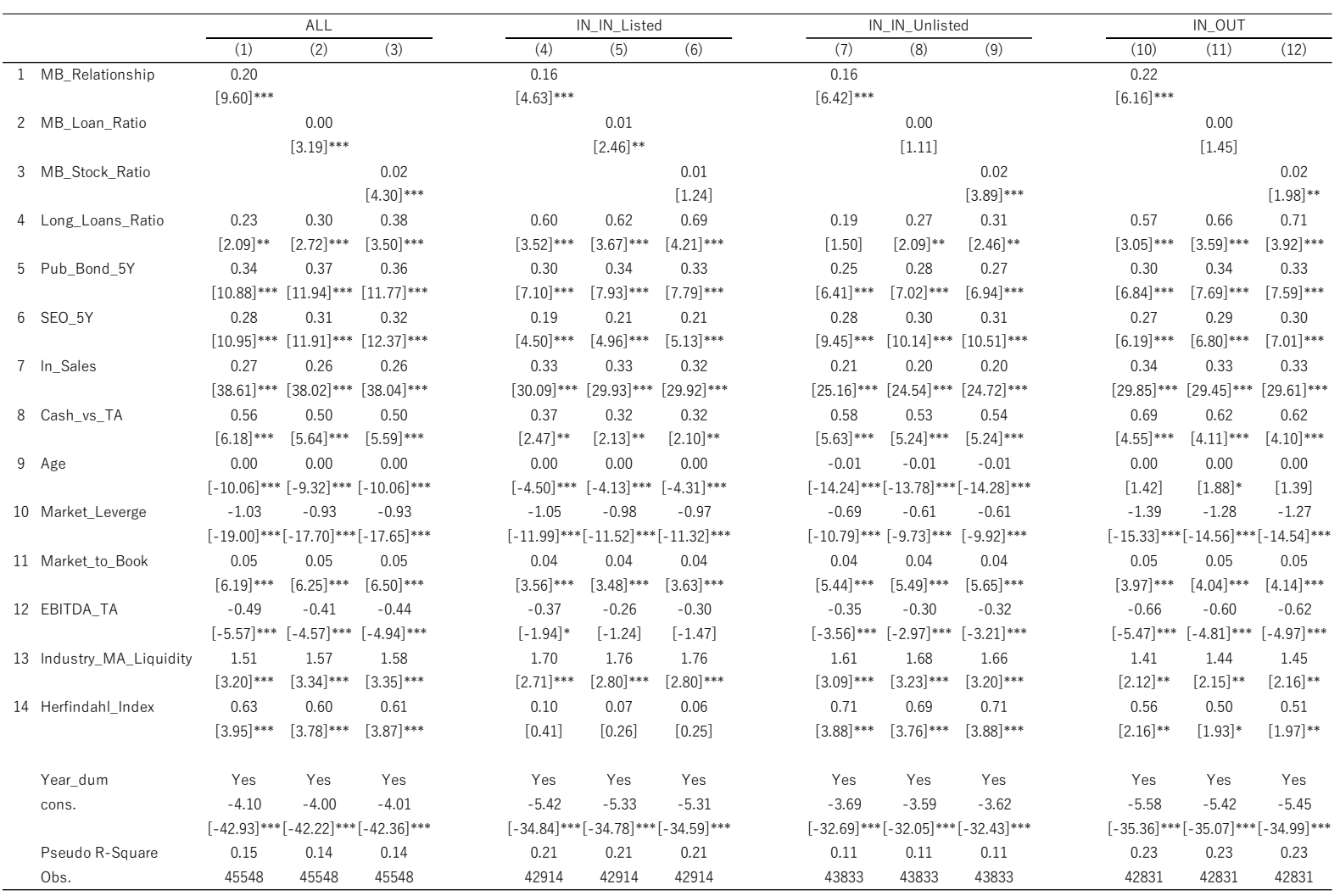

Notes: This table presents the result of probit regressions for estimating the probability of Japanese bidders choosing an M\&A. In regressions (1), (2) and (3), the dependent variable is dummy variables which equals to 1 when an M\&A deal was done and the size of the M\&A is greater than 100 million yen, and 0 for others who did not M\&A during the fiscal year. In regressions (4), (5) and (6), the dependent variable is dummy variables which equals to 1 when an IN-IN-LISTED M\&A deal was done and the size of the IN-IN-LISTED M\&A is greater than 100 million yen, and 0 for others who did not M\&A during the fiscal year. In regressions (7), (8) and (9), the dependent variable is dummy variables which equals to 1 when an IN-IN-UNLISTED M\&A deal was done and the size of the IN-IN-UNLISTED M\&A is greater than 100 million yen, and 0 for others who did not M\&A during the fiscal year. In regressions (10), (11) and (12), the dependent variable is dummy variables which equals to 1 when an IN-OUT M\&A deal was done and the size of the IN-OUT M\&A is greater than 100 million yen, and 0 for others who did not M\&A during the fiscal year. All accounting data are taken at fiscal year-end prior to the M\&A deal. Z-statistics based on cluster-adjusted robust standard errors (Petersen, 2009). ***, **, * represent significance at $1 \%, 5 \%$, and $10 \%$ respectively. 
Table 3B: Tobit results

\begin{tabular}{|c|c|c|c|c|c|c|c|c|c|c|c|c|c|}
\hline & & \multicolumn{3}{|c|}{ ALL } & \multicolumn{3}{|c|}{ IN_IN_Listed } & \multicolumn{3}{|c|}{ IN IN Unlisted } & \multicolumn{3}{|c|}{ IN_OUT } \\
\hline & & (1) & (2) & (3) & (4) & (5) & (6) & (7) & (8) & (9) & (10) & (11) & (12) \\
\hline \multirow[t]{2}{*}{1} & MB_Relationship & 0.06 & & & 0.06 & & & 0.03 & & & 0.08 & & \\
\hline & & {$[8.14]^{* * *}$} & & & {$[4.42] * * *$} & & & {$[5.57]^{* * *}$} & & & {$[5.12]^{* * *}$} & & \\
\hline \multirow[t]{2}{*}{2} & MB_Loan_Ratio & & 0.00 & & & 0.00 & & & 0.00 & & & 0.00 & \\
\hline & & & {$[2.65]^{* * *}$} & & & {$[2.22]^{* *}$} & & & [1.18] & & & {$[0.94]$} & \\
\hline \multirow[t]{2}{*}{3} & MB_Stock_Ratio & & & 0.00 & & & 0.00 & & & 0.00 & & & 0.00 \\
\hline & & & & {$[2.58]^{* * *}$} & & & {$[0.37]$} & & & {$[3.21]^{* * *}$} & & & {$[1.26]$} \\
\hline \multirow[t]{2}{*}{4} & Long_Loans_Ratio & 0.09 & 0.11 & 0.13 & 0.20 & 0.21 & 0.24 & 0.04 & 0.06 & 0.07 & 0.21 & 0.25 & 0.26 \\
\hline & & {$[2.15]^{* *}$} & {$[2.72]^{* * *}$} & {$[3.39] * * *$} & {$[3.00] * * *$} & {$[3.19] * * *$} & {$[3.66]^{* * *}$} & [1.34] & [1.86]* $]^{*}$ & {$[2.22]^{* *}$} & {$[2.47] * *$} & {$[2.97]^{* * *}$} & {$[3.19]^{* * *}$} \\
\hline \multirow[t]{2}{*}{5} & Pub_Bond_5Y & 0.11 & 0.12 & 0.12 & 0.11 & 0.12 & 0.12 & 0.06 & 0.07 & 0.07 & 0.13 & 0.14 & 0.14 \\
\hline & & {$[9.67]^{* * *}$} & {$[10.50]^{* * *}$} & {$[10.39]^{* * *}$} & {$[6.33]^{* * *}$} & {$[7.06] * * *$} & {$[6.96]^{* * *}$} & {$[6.42]^{* * *}$} & {$[6.90]^{* * *}$} & {$[6.85]^{* * *}$} & {$[6.32]^{* * *}$} & {$[6.95]^{* * *}$} & {$[6.90] * * *$} \\
\hline \multirow[t]{2}{*}{6} & SEO_5Y & 0.09 & 0.10 & 0.10 & 0.06 & 0.07 & 0.07 & 0.07 & 0.08 & 0.08 & 0.10 & 0.11 & 0.11 \\
\hline & & {$[9.85]^{* * *}$} & {$[10.68]^{* * *}$} & {$[10.96]^{* * *}$} & {$[3.54]^{* * *}$} & {$[4.00] * * *$} & {$[4.06]^{* * *}$} & {$[9.78]^{* * *}$} & {$[10.38]^{* * *}$} & {$[10.68]^{* * *}$} & {$[5.03]^{* * *}$} & {$[5.53]^{* * *}$} & {$[5.66]^{* * *}$} \\
\hline \multirow[t]{2}{*}{7} & In_Sales & 0.07 & 0.07 & 0.07 & 0.11 & 0.11 & 0.10 & 0.04 & 0.04 & 0.04 & 0.13 & 0.12 & 0.12 \\
\hline & & {$[28.37]^{* * *}$} & {$[27.96]^{* * *}$} & {$[27.95]^{* * *}$} & {$[22.04]^{* * *}$} & {$[21.92]^{* * *}$} & $*[21.90] * * *$ & {$[18.69]^{* * *}$} & {$[18.31]^{* * *}$} & {$[18.36]^{* * *}$} & {$[21.87]^{* * *}$} & {$[21.60]^{* * *} \mid$} & {$[21.74]^{* * *}$} \\
\hline \multirow[t]{2}{*}{8} & Cash_vs_TA & 0.25 & 0.23 & 0.23 & 0.18 & 0.16 & 0.16 & 0.18 & 0.17 & 0.17 & 0.28 & 0.26 & 0.26 \\
\hline & & {$[7.85]^{* * *}$} & {$[7.40]^{* * *}$} & {$[7.37]^{* * *}$} & {$[3.09] * * *$} & {$[2.78] * * *$} & {$[2.74]^{* * *}$} & {$[7.26]^{* * *}$} & {$[6.94]^{* * *}$} & {$[6.95]^{* * *}$} & {$[4.22]^{* * *}$} & {$[3.85]^{* * *}$} & {$[3.84] * * *$} \\
\hline \multirow[t]{2}{*}{9} & Age & 0.00 & 0.00 & 0.00 & 0.00 & 0.00 & 0.00 & 0.00 & 0.00 & 0.00 & 0.00 & 0.00 & 0.00 \\
\hline & & {$[-9.08]^{* * *}$} & {$[-8.48]^{* * *}$} & {$[-8.84]^{* * *}$} & {$[-3.85]^{* * *}$} & {$[-3.51]^{* * *}$} & $*[-3.49] * * *$ & {$[-13.21]^{* * *}$} & {$[-12.85]^{* * *}$} & {$[-13.18]^{* * *}$} & [1.19] & [1.57] & [1.23] \\
\hline \multirow[t]{2}{*}{10} & Market_Leverge & -0.39 & -0.36 & -0.36 & -0.41 & -0.39 & -0.38 & -0.19 & -0.17 & -0.17 & -0.60 & -0.55 & -0.55 \\
\hline & & {$[-20.00]^{* * *}$} & {$[-19.01]^{* * *}$} & {$[-18.95]^{* * *}$} & {$[-11.92] * *$} & {$[-11.54] * * *$} & $*[-11.35]^{* * *}$ & {$[-12.21] * * *$} & {$[-11.40]^{* * *}$} & {$[-11.56]^{* * *}$} & {$[-14.02]^{* * *}$} & {$[-13.48]^{* * *[}$} & {$[-13.49]^{* * *}$} \\
\hline \multirow[t]{2}{*}{11} & Market_to_Book & 0.01 & 0.01 & 0.01 & 0.02 & 0.02 & 0.02 & 0.00 & 0.00 & 0.00 & 0.02 & 0.02 & 0.02 \\
\hline & & {$[5.56]^{* * *}$} & {$[5.51]^{* * *}$} & {$[5.58]^{* * *}$} & {$[4.28] * * *$} & {$[4.26] * * *$} & {$[4.32] * * *$} & {$[5.80]^{* * *}$} & {$[5.75]^{* * *}$} & {$[5.82] * * *$} & {$[4.05]^{* * *}$} & {$[4.10] * * *$} & {$[4.17]^{* * *}$} \\
\hline \multirow[t]{2}{*}{12} & EBITDA_TA & -0.23 & -0.21 & -0.21 & -0.19 & -0.16 & -0.17 & -0.13 & -0.13 & -0.13 & -0.28 & -0.26 & -0.26 \\
\hline & & {$[-7.93]^{* * *}$} & {$[-7.15]^{* * *}$} & {$[-7.40] * * *$} & {$[-3.55]^{* * *}$} & {$[-2.90]^{* * *}$} & $*[-3.09] * * *$ & {$[-6.52]^{* * *}$} & {$[-6.04]^{* * *}$} & {$[-6.24] * * *$} & {$[-5.47]^{* * *}$} & {$[-4.99] * * *$} & {$[-5.07] * * *$} \\
\hline \multirow[t]{2}{*}{13} & Industry_MA_Liquid & 0.64 & 0.66 & 0.66 & 0.63 & 0.66 & 0.66 & 0.42 & 0.44 & 0.43 & 0.65 & 0.67 & 0.67 \\
\hline & & {$[3.81]^{* * *}$} & {$[3.93]^{* * *}$} & {$[3.95] * * *$} & {$[2.59]^{* * *}$} & {$[2.68]^{* * *}$} & {$[2.70]^{* * *}$} & {$[3.31]^{* * *}$} & {$[3.44]^{* * *}$} & {$[3.41]^{* * *}$} & {$[2.25] * *$} & {$[2.29] * *$} & {$[2.30] * *$} \\
\hline \multirow[t]{10}{*}{14} & Herfindahl_Index & 0.18 & 0.18 & 0.18 & 0.02 & 0.01 & 0.00 & 0.15 & 0.14 & 0.15 & 0.28 & 0.26 & 0.26 \\
\hline & & {$[3.19]^{* * *}$} & {$[3.08]^{* * *}$} & {$[3.13]^{* * *}$} & {$[0.21]$} & {$[0.07]$} & {$[0.03]$} & {$[3.19]^{* * *}$} & {$[3.12]^{* * *}$} & {$[3.21]^{* * *}$} & {$[2.40]^{* *}$} & {$[2.23]^{* *}$} & {$[2.25]^{* *}$} \\
\hline & Year_dum & Yes & Yes & Yes & Yes & Yes & Yes & Yes & Yes & Yes & Yes & Yes & Yes \\
\hline & cons. & -1.25 & -1.22 & -1.22 & -1.89 & -1.86 & -1.84 & -0.79 & -0.77 & -0.77 & -2.24 & -2.18 & -2.19 \\
\hline & & {$[-33.59]^{* * *}$} & {$[-33.11]^{* * *}$} & {$[-33.12]^{* * *}$} & {$[-25.59] * *$} & {$[-25.54] * * *$} & $*[-25.37]^{* * *}$ & {$[-25.50] * * *$} & {$[-25.13]^{* * *}$} & {$[-25.32]^{* * *}$} & {$[-25.84]^{* * *}$} & {$[-25.69] * * *[$} & {$[-25.64]^{* * *}$} \\
\hline & Sigma & & & & & & & & & & & & \\
\hline & cons. & 0.36 & 0.36 & 0.36 & 0.39 & 0.39 & 0.39 & 0.25 & 0.25 & 0.25 & 0.45 & 0.45 & 0.45 \\
\hline & & {$[80.77]^{* * *}$} & {$[80.78]^{* * *}$} & {$[80.76]^{* * *}$} & {$[44.32]^{* * *}$} & {$[44.32]^{* * *}$} & $*[44.30] * * *$ & {$[57.81]^{* * *}$} & {$[57.82] * * *$} & {$[57.82] * * *$} & {$[43.71]^{* * *}$} & {$[43.73]^{* * *} \mid$} & [43.72]*** \\
\hline & Pseudo R-Square & 0.15 & 0.15 & 0.15 & 0.22 & 0.22 & 0.22 & 0.15 & 0.15 & 0.15 & 0.23 & 0.23 & 0.23 \\
\hline & Obs. & 45548 & 45548 & 45548 & 42914 & 42914 & 42914 & 43833 & 43833 & 43833 & 42831 & 42831 & 42831 \\
\hline
\end{tabular}

Notes: This table presents the result of tobit regressions for estimating the probability of Japanese bidders choosing an M\&A. In regressions (1), (2) and (3), the dependent variable is dummy variables which equals to 1 when an M\&A deal was done and the size of the M\&A is greater than 100 million yen, and 0 for others who did not M\&A during the fiscal year. In regressions (4), (5) and (6), the dependent variable is dummy variables which equals to 1 when an IN-IN-LISTED M\&A deal was done and the size of the IN-IN-LISTED M\&A is greater than 100 million yen, and 0 for others who did not M\&A during the fiscal year. In regressions (7), (8) and (9), the dependent variable is dummy variables which equals to 1 when an IN-IN-UNLISTED M\&A deal was done and the size of the IN-IN-UNLISTED M\&A is greater than 100 million yen, and 0 for others who did not M\&A during the fiscal year. In regressions (10), (11) and (12), the dependent variable is dummy variables which equals to 1 when an IN-OUT M\&A deal was done and the size of the IN-OUT M\&A is greater than 100 million yen, and 0 for others who did not M\&A during the fiscal year. All accounting data are taken at fiscal year-end prior to the M\&A deal. Z-statistics based on cluster-adjusted robust standard errors (Petersen, 2009). ***, **, * represent significance at $1 \%, 5 \%$, and $10 \%$ respectively. 
Table 4A: Segmented Sample Probit Results

\begin{tabular}{|c|c|c|c|c|c|c|c|c|c|}
\hline & & \multicolumn{2}{|c|}{ ALL } & \multicolumn{2}{|c|}{ IN_IN_Listed } & \multicolumn{2}{|c|}{ IN_IN_Unlisted } & \multicolumn{2}{|c|}{ IN_OUT } \\
\hline & & (1) & (2) & (3) & (4) & (5) & (6) & (7) & (8) \\
\hline \multirow[t]{2}{*}{1} & MB_Relationship_Loan_Stock & -0.10 & & -0.09 & & -0.08 & & -0.11 & \\
\hline & & {$[-3.99] * * *$} & & {$[-2.42]^{* *}$} & & {$[-2.76]^{* * *}$} & & {$[-2.68]^{* * *}$} & \\
\hline \multirow[t]{2}{*}{2} & MB_Stock_Ratio_Biggest_Lender & & -0.01 & & -0.02 & & -0.01 & & -0.02 \\
\hline & & & {$[-2.26]^{* *}$} & & {$[-2.26]^{* *}$} & & {$[-0.89]$} & & {$[-1.58]$} \\
\hline \multirow[t]{2}{*}{3} & Long_Loans_Ratio & 0.40 & 0.41 & 0.81 & 0.80 & 0.43 & 0.44 & 0.49 & 0.50 \\
\hline & & {$[3.08]^{* * *}$} & {$[3.12]^{* * *}$} & {$[4.03]^{* * *}$} & {$[4.00]^{* * *}$} & {$[2.87]^{* * *}$} & {$[2.95]^{* * *}$} & {$[2.20]^{* *}$} & {$[2.22]^{* *}$} \\
\hline \multirow[t]{2}{*}{4} & Pub_Bond_5Y & 0.21 & 0.21 & 0.22 & 0.22 & 0.14 & 0.14 & 0.11 & 0.11 \\
\hline & & {$[5.62] * * *$} & {$[5.60]^{* * *}$} & {$[4.10]^{* * *}$} & {$[4.04]^{* * *}$} & {$[2.84]^{* * *}$} & {$[2.87]^{* * *}$} & {$[2.05]^{* *}$} & {$[2.03]^{* *}$} \\
\hline \multirow[t]{2}{*}{5} & SEO_5Y & 0.27 & 0.27 & 0.20 & 0.19 & 0.26 & 0.27 & 0.26 & 0.26 \\
\hline & & {$[8.30]^{* * *}$} & {$[8.37]^{* * *}$} & {$[3.82]^{* * *}$} & {$[3.73]^{* * *}$} & {$[7.02]^{* * *}$} & {$[7.16]^{* * *}$} & {$[4.94] * * *$} & {$[4.95]^{* * *}$} \\
\hline \multirow[t]{2}{*}{6} & In_Sales & 0.29 & 0.29 & 0.35 & 0.35 & 0.22 & 0.22 & 0.39 & 0.39 \\
\hline & & \multicolumn{2}{|c|}{$[30.18]^{* * *}[30.21]^{* * *}$} & \multicolumn{2}{|c|}{$[23.28]^{* * *}[23.27]^{* * *}$} & \multicolumn{2}{|c|}{$[19.61]^{* * *}[19.66]^{* * *}$} & \multicolumn{2}{|c|}{$[24.68]^{* * *}[24.69]^{* * *}$} \\
\hline \multirow[t]{2}{*}{7} & Cash_vs_TA & 0.72 & 0.74 & 0.34 & 0.35 & 0.91 & 0.92 & 0.59 & 0.61 \\
\hline & & {$[5.11] * * *$} & {$[5.23]^{* * *}$} & {$[1.42]$} & {$[1.47]$} & {$[5.65]^{* * *}$} & {$[5.75]^{* * *}$} & {$[2.37]^{* *}$} & {$[2.44]^{* *}$} \\
\hline \multirow[t]{2}{*}{8} & Age & 0.00 & 0.00 & 0.00 & 0.00 & -0.01 & -0.01 & 0.00 & 0.00 \\
\hline & & {$[-6.15] * * *$} & {$[-6.26] * * *$} & {$[-2.22]^{* *}$} & {$[-2.14] * *$} & {$[-8.95]^{* * *}$} & {$[-9.16]^{* * *}$} & [0.99] & {$[0.93]$} \\
\hline \multirow[t]{2}{*}{9} & Market_Leverge & -0.84 & -0.85 & -0.93 & -0.93 & -0.53 & -0.54 & -1.30 & -1.30 \\
\hline & & \multicolumn{2}{|c|}{$[-11.08]^{* * *}[-11.12]^{* * *}$} & \multicolumn{2}{|c|}{$[-7.23]^{* * *}[-7.18]^{* * *}$} & \multicolumn{2}{|c|}{$[-5.92]^{* * *}[-6.02]^{* * *}$} & \multicolumn{2}{|c|}{$[-10.03] * * *[-10.04] * * *$} \\
\hline \multirow[t]{2}{*}{10} & Market_to_Book & 0.05 & 0.05 & 0.02 & 0.02 & 0.05 & 0.05 & 0.02 & 0.02 \\
\hline & & {$[3.58]^{* * *}$} & {$[3.70]^{* * *}$} & {$[0.62]$} & {$[0.66]$} & {$[3.54]^{* * *}$} & {$[3.64]^{* * *}$} & {$[0.64]$} & {$[0.73]$} \\
\hline \multirow[t]{2}{*}{11} & EBITDA_TA & -0.82 & -0.83 & -0.20 & -0.21 & -0.62 & -0.64 & -1.48 & -1.49 \\
\hline & & {$[-4.30] * * *$} & {$[-4.36] * * *$} & {$[-0.48]$} & {$[-0.50]$} & {$[-3.00]^{* * *}$} & {$[-3.06]^{* * *}$} & {$[-4.72]^{* * *}$} & {$[-4.76]^{* * *}$} \\
\hline \multirow[t]{2}{*}{12} & Industry_MA_Liquidity & 1.08 & 1.07 & 1.45 & 1.45 & 1.43 & 1.43 & 0.25 & 0.26 \\
\hline & & {$[1.89]^{*}$} & {$[1.88]^{*}$} & {$[1.83]^{*}$} & {$[1.84]^{*}$} & {$[2.37]^{* *}$} & {$[2.36]^{* *}$} & {$[0.23]$} & {$[0.24]$} \\
\hline \multirow[t]{7}{*}{13} & Herfindahl_Index & 0.66 & 0.68 & -0.26 & -0.25 & 0.71 & 0.75 & 0.61 & 0.63 \\
\hline & & {$[3.24]^{* * *}$} & {$[3.37]^{* * *}$} & {$[-0.78]$} & {$[-0.76]$} & {$[3.01]^{* * *}$} & {$[3.15]^{* * *}$} & {$[1.87]^{*}$} & [1.93]* \\
\hline & Year_dum & Yes & Yes & Yes & Yes & Yes & Yes & Yes & Yes \\
\hline & cons. & -4.19 & -4.24 & -5.46 & -5.48 & -3.81 & -3.86 & -5.73 & -5.78 \\
\hline & & \multicolumn{2}{|c|}{$[-32.62] * * *[-33.03]^{* * *}$} & \multicolumn{2}{|c|}{$[-25.77] * * *[-25.90] * * *$} & \multicolumn{2}{|c|}{$[-25.19] * * *[-25.56] * * *$} & {$[-26.70]^{* * *}$} & {$[-26.95] * * *$} \\
\hline & Pseudo R-Square & 0.14 & 0.14 & 0.22 & 0.22 & 0.10 & 0.10 & 0.24 & 0.24 \\
\hline & Obs. & 26736 & 26736 & 25101 & 25101 & 25637 & 25637 & 25051 & 25051 \\
\hline
\end{tabular}

Notes: This table presents the result of probit regressions for estimating the probability of Japanese bidders with a main banking relationship choosing an M\&A. In regressions (1) and (2), the dependent variable is dummy variables which equals to 1 when an M\&A deal was done and the size of the M\&A is greater than 100 million yen, and 0 for others who did not M\&A during the fiscal year. In regressions (3) and (4), the dependent variable is dummy variables which equals to 1 when an IN-IN-LISTED M\&A deal was done and the size of the IN-INLISTED M\&A is greater than 100 million yen, and 0 for others who did not M\&A during the fiscal year. In regressions (5) and (6), the dependent variable is dummy variables which equals to 1 when an IN-IN-UNLISTED M\&A deal was done and the size of the IN-IN-UNLISTED M\&A is greater than 100 million yen, and 0 for others who did not M\&A during the fiscal year. In regressions (7) and (8), the dependent variable is dummy variables which equals to 1 when an IN-OUT M\&A deal was done and the size of the IN-OUT M\&A is greater than 100 million yen, and 0 for others who did not M\&A during the fiscal year. All accounting data are taken at fiscal yearend prior to the M\&A deal. Z-statistics based on cluster-adjusted robust standard errors (Petersen, 2009). ***, **, $*$ represent significance at $1 \%, 5 \%$, and $10 \%$ respectively. 
Table 4B: Segmented Sample Tobit Results

\begin{tabular}{|c|c|c|c|c|c|c|c|c|c|}
\hline & & \multicolumn{2}{|c|}{ ALL } & \multicolumn{2}{|c|}{ IN_IN_Listed } & \multicolumn{2}{|c|}{ IN_IN_Unlisted } & \multicolumn{2}{|c|}{ IN_OUT } \\
\hline & & (1) & (2) & (4) & (5) & (7) & (8) & (9) & (10) \\
\hline \multirow[t]{2}{*}{1} & MB_Relationship_Loan_Stock & -0.02 & & -0.03 & & -0.01 & & -0.01 & \\
\hline & & {$[-3.92]^{* * *}$} & & {$[-2.60]^{* *}$} & & {$[-2.71]^{* * *}$} & & {$[-2.12]^{* *}$} & \\
\hline \multirow[t]{2}{*}{2} & MB_Stock_Ratio_Biggest_Lender & & 0.00 & & -0.01 & & 0.00 & & 0.00 \\
\hline & & & {$[-2.26]^{* *}$} & & {$[-2.58]^{* *}$} & & {$[-0.68]$} & & {$[-1.14]$} \\
\hline \multirow[t]{2}{*}{3} & Long_Loans_Ratio & 0.06 & 0.06 & 0.19 & 0.19 & 0.05 & 0.05 & 0.04 & 0.04 \\
\hline & & {$[2.41]^{* *}$} & {$[2.46] * *$} & {$[3.38]^{* * *}$} & {$[3.34]^{* * *}$} & {$[2.13]^{* *}$} & {$[2.22]^{* *}$} & {$[1.30]$} & [1.32] \\
\hline \multirow[t]{2}{*}{4} & Pub_Bond_5Y & 0.04 & 0.04 & 0.06 & 0.05 & 0.02 & 0.02 & 0.02 & 0.02 \\
\hline & & {$[5.02]^{* * *}$} & {$[4.99]^{* * *}$} & {$[3.59]^{* * *}$} & {$[3.52]^{* * *}$} & {$[3.11]^{* * *}$} & {$[3.15]^{* * *}$} & {$[2.18]^{* *}$} & {$[2.16]^{* *}$} \\
\hline \multirow[t]{2}{*}{5} & SEO_5Y & 0.05 & 0.05 & 0.04 & 0.04 & 0.04 & 0.04 & 0.03 & 0.03 \\
\hline & & {$[7.52]^{* * *}$} & {$[7.59]^{* * *}$} & {$[2.76]^{* * *}$} & {$[2.65]^{* * *}$} & {$[7.44]^{* * *}$} & {$[7.60]^{* * *}$} & {$[4.44]^{* * *}$} & {$[4.47]^{* * *}$} \\
\hline \multirow[t]{2}{*}{6} & In_Sales & 0.05 & 0.05 & 0.08 & 0.08 & 0.03 & 0.03 & 0.04 & 0.05 \\
\hline & & {$[23.04]^{* * *}$} & {$[23.08]^{* * *}$} & {$[17.28]^{* *}$} & {$[17.28]^{* * *}$} & {$[14.61]^{* * *}$} & {$[14.66]^{* * *}$} & {$[19.00]^{* * *}$} & {$[19.01]^{* * *}$} \\
\hline \multirow[t]{2}{*}{7} & Cash_vs_TA & 0.17 & 0.18 & 0.14 & 0.14 & 0.16 & 0.16 & 0.07 & 0.08 \\
\hline & & {$[6.35]^{* * *}$} & {$[6.47]^{* * *}$} & {$[2.08]^{* *}$} & {$[2.14] * *$} & {$[6.67] * * *$} & {$[6.77]^{* * *}$} & {$[2.33]^{* *}$} & {$[2.40]^{* *}$} \\
\hline \multirow[t]{2}{*}{8} & Age & 0.00 & 0.00 & 0.00 & 0.00 & 0.00 & 0.00 & 0.00 & 0.00 \\
\hline & & {$[-6.16]^{* * *}$} & {$[-6.27]^{* * *}$} & {$[-2.25]^{* *}$} & {$[-2.14] * *$} & {$[-8.45]^{* * *}$} & {$[-8.71] * * *$} & {$[0.45]$} & {$[0.39]$} \\
\hline \multirow[t]{2}{*}{9} & Market_Leverge & -0.18 & -0.18 & -0.26 & -0.26 & -0.09 & -0.09 & -0.17 & -0.17 \\
\hline & & {$[-12.08]^{* * *}$} & {$[-12.12]^{* * *}$} & {$[-7.39]^{* *}$} & {$[-7.33] * * *$} & {$[-6.84] * * *$} & {$[-6.97]^{* * *}$} & {$[-9.96]^{* * *}$} & {$[-9.97] * * *$} \\
\hline \multirow[t]{2}{*}{10} & Market_to_Book & 0.01 & 0.01 & 0.01 & 0.01 & 0.01 & 0.01 & 0.00 & 0.00 \\
\hline & & {$[5.85]^{* * *}$} & {$[5.97]^{* * *}$} & {$[1.89]^{*}$} & {$[1.92] *$} & {$[5.97]^{* * *}$} & {$[6.08]^{* * *}$} & [1.37] & [1.45] \\
\hline \multirow[t]{2}{*}{11} & EBITDA_TA & -0.21 & -0.21 & -0.06 & -0.07 & -0.17 & -0.17 & -0.18 & -0.18 \\
\hline & & {$[-6.12]^{* * *}$} & {$[-6.18]^{* * *}$} & {$[-0.59]$} & {$[-0.61]$} & {$[-6.10] * * *$} & {$[-6.18]^{* * *}$} & {$[-4.41]^{* * *}$} & {$[-4.45]^{* * *}$} \\
\hline \multirow[t]{2}{*}{12} & Industry_MA_Liquidity & 0.33 & 0.33 & 0.38 & 0.38 & 0.22 & 0.22 & 0.20 & 0.20 \\
\hline & & {$[3.06]^{* * *}$} & {$[3.06]^{* * *}$} & {$[1.76]^{*}$} & {$[1.76]^{*}$} & {$[2.52]^{* *}$} & {$[2.51]^{* *}$} & {$[2.09]^{* *}$} & {$[2.10]^{* *}$} \\
\hline \multirow[t]{10}{*}{13} & Herfindahl_Index & 0.11 & 0.12 & -0.07 & -0.06 & 0.11 & 0.12 & 0.09 & 0.09 \\
\hline & & {$[2.80]^{* * *}$} & {$[2.93]^{* * *}$} & {$[-0.70]$} & {$[-0.68]$} & {$[3.21]^{* * *}$} & {$[3.37]^{* * *}$} & {$[2.06]^{* *}$} & {$[2.12]^{* *}$} \\
\hline & Year_dum & Yes & Yes & Yes & Yes & Yes & Yes & Yes & Yes \\
\hline & cons. & -0.71 & -0.72 & -1.37 & -1.37 & -0.50 & -0.51 & -0.70 & -0.70 \\
\hline & & {$[-26.29]^{* * *}$} & {$[-26.61] * * *$} & {$[-19.52]^{* *}$} & $*[-19.58] * * *$ & {$[-19.99]^{* *}$} & {$[-20.27] * * *$} & {$[-20.51] * * *$} & $4[-20.63]^{* * *}$ \\
\hline & Sigma & & & & & & & & \\
\hline & cons. & 0.20 & 0.20 & 0.28 & 0.28 & 0.15 & 0.15 & 0.13 & 0.13 \\
\hline & & {$[62.65]^{* * *}$} & {$[62.64]^{* * *}$} & {$[34.87]^{* *}$} & {$[34.87]^{* * *}$} & {$[44.41]^{* * *}$} & {$[44.41]^{* * *}$} & {$[33.51]^{* * *}$} & {$[33.51]^{* * *}$} \\
\hline & Pseudo R-Square & 0.20 & 0.20 & 0.24 & 0.24 & 0.17 & 0.17 & 0.38 & 0.38 \\
\hline & Obs. & 26736 & 26736 & 25101 & 25101 & 25637 & 25637 & 25051 & 25051 \\
\hline
\end{tabular}

Notes: This table presents the result of tobit regressions for estimating the probability of Japanese bidders with a main banking relationship choosing an M\&A. In regressions (1) and (2), the dependent variable is dummy variables which equals to 1 when an M\&A deal was done and the size of the M\&A is greater than 100 million yen, and 0 for others who did not M\&A during the fiscal year. In regressions (3) and (4), the dependent variable is dummy variables which equals to 1 when an IN-IN-LISTED M\&A deal was done and the size of the IN-INLISTED M\&A is greater than 100 million yen, and 0 for others who did not M\&A during the fiscal year. In regressions (5) and (6), the dependent variable is dummy variables which equals to 1 when an IN-IN-UNLISTED M\&A deal was done and the size of the IN-IN-UNLISTED M\&A is greater than 100 million yen, and 0 for others who did not M\&A during the fiscal year. In regressions (7) and (8), the dependent variable is dummy variables which equals to 1 when an IN-OUT M\&A deal was done and the size of the IN-OUT M\&A is greater than 100 million yen, and 0 for others who did not M\&A during the fiscal year. All accounting data are taken at fiscal yearend prior to the M\&A deal. Z-statistics based on cluster-adjusted robust standard errors (Petersen, 2009). ***, **, $*$ represent significance at $1 \%, 5 \%$, and $10 \%$ respectively. 
Table 5A: Probit results for firms with stable bank relationships

\begin{tabular}{|c|c|c|c|c|c|}
\hline & & \begin{tabular}{c|}
$A L L$ \\
$(1)$
\end{tabular} & $\frac{\text { IN_IN_Listed }}{(2)}$ & $\frac{\text { IN_IN_Unlisted }}{(3)}$ & $\frac{\text { IN_OUT }}{(4)}$ \\
\hline \multirow[t]{2}{*}{1} & MB_Relationship_Loan_5Y & 0.16 & 0.14 & 0.13 & 0.17 \\
\hline & & {$[7.73]^{* * *}$} & {$[4.34] * * *$} & {$[5.28] * * *$} & {$[4.85]^{* * *}$} \\
\hline \multirow[t]{2}{*}{2} & Long_Loans_Ratio & 0.27 & 0.61 & 0.22 & 0.61 \\
\hline & & {$[2.47]^{* *}$} & {$[3.63]^{* * *}$} & {$[1.75]^{*}$} & {$[3.28]^{* * *}$} \\
\hline \multirow[t]{2}{*}{3} & Pub_Bond_5Y & 0.35 & 0.31 & 0.26 & 0.31 \\
\hline & & {$[11.20]^{* * *}$} & {$[7.29] * * *$} & {$[6.60]^{* * *}$} & {$[7.11]^{* * *}$} \\
\hline \multirow[t]{2}{*}{4} & SEO_5Y & 0.33 & 0.22 & 0.31 & 0.31 \\
\hline & & {$[12.57]^{* * *}$} & {$[5.21] * * *$} & {$[10.62]^{* * *}$} & {$[7.05] * * *$} \\
\hline \multirow[t]{2}{*}{5} & In_Sales & 0.27 & 0.33 & 0.21 & 0.34 \\
\hline & & {$[38.42]^{* * *}$} & {$[30.06]^{* * *}$} & {$[25.01]^{* * *}$} & {$[29.73]^{* * *}$} \\
\hline \multirow[t]{2}{*}{6} & Cash_vs_TA & 0.52 & 0.35 & 0.55 & 0.66 \\
\hline & & {$[5.86]^{* * *}$} & {$[2.34] * *$} & {$[5.40] * * *$} & {$[4.34] * * *$} \\
\hline \multirow[t]{2}{*}{7} & Age & 0.00 & 0.00 & -0.01 & 0.00 \\
\hline & & {$[-10.42]^{* * *}$} & {$[-4.80]^{* * *}$} & {$[-14.42] * * *$} & [1.10] \\
\hline \multirow[t]{2}{*}{8} & Market_Leverge & -1.01 & -1.05 & -0.67 & -1.37 \\
\hline & & {$[-18.61]^{* * *}$} & {$[-11.95]^{* * *}$} & {$[-10.54] * * *$} & {$[-15.06]^{* * *}$} \\
\hline \multirow[t]{2}{*}{9} & Market_to_Book & 0.05 & 0.04 & 0.04 & 0.05 \\
\hline & & {$[6.16]^{* * *}$} & {$[3.51] * * *$} & {$[5.41] * * *$} & {$[3.93]^{* * *}$} \\
\hline \multirow[t]{2}{*}{10} & EBITDA_TA & -0.48 & -0.37 & -0.34 & -0.65 \\
\hline & & {$[-5.45]^{* * *}$} & {$[-1.98]^{* *}$} & {$[-3.50]^{* * *}$} & {$[-5.38]^{* * *}$} \\
\hline \multirow[t]{2}{*}{11} & Industry_MA_Liquidity & 1.54 & 1.72 & 1.64 & 1.42 \\
\hline & & {$[3.27]^{* * *}$} & {$[2.75] * * *$} & {$[3.14] * * *$} & {$[2.13]^{* *}$} \\
\hline \multirow[t]{7}{*}{12} & Herfindahl_Index & 0.62 & 0.10 & 0.71 & 0.54 \\
\hline & & {$[3.92]^{* * *}$} & {$[0.39]$} & {$[3.86] * * *$} & {$[2.08]^{* *}$} \\
\hline & Year_dum & Yes & Yes & Yes & Yes \\
\hline & cons. & -4.01 & -5.36 & -3.61 & -5.48 \\
\hline & & {$[-42.49] * * *$} & {$[-34.88]^{* * *}$} & {$[-32.42] * * *$} & {$[-35.27]^{* * *}$} \\
\hline & Pseudo R-Square & 0.15 & 0.21 & 0.11 & 0.23 \\
\hline & Obs. & 45548 & 42914 & 43833 & 42831 \\
\hline
\end{tabular}

Notes: This table presents the result of probit regressions for estimating the probability of Japanese bidders choosing an M\&A. In regression (1) the dependent variable is dummy variables which equals to 1 when an M\&A deal was done and the size of the M\&A is greater than 100 million yen, and 0 for others who did not M\&A during the fiscal year. In regression (2) the dependent variable is dummy variables which equals to 1 when an IN-INLISTED M\&A deal was done and the size of the IN-IN-LISTED M\&A is greater than 100 million yen, and 0 for others who did not M\&A during the fiscal year. In regression (3) the dependent variable is dummy variables which equals to 1 when an IN-IN-UNLISTED M\&A deal was done and the size of the IN-IN-UNLISTED M\&A is greater than 100 million yen, and 0 for others who did not M\&A during the fiscal year. In regression (4), the dependent variable is dummy variables which equals to 1 when an IN-OUT M\&A deal was done and the size of the IN-OUT M\&A is greater than 100 million yen, and 0 for others who did not M\&A during the fiscal year. All accounting data are taken at fiscal year-end prior to the M\&A deal. Z-statistics based on cluster-adjusted robust standard errors (Petersen, 2009). ***,**,* represent significance at $1 \%, 5 \%$, and $10 \%$ respectively. 
Table 5B: Probit results for firms with stable bank relationships within segmented sample

\begin{tabular}{|c|c|c|c|c|c|}
\hline & & $\frac{A L L}{(1)}$ & $\frac{\text { IN_IN_Listed }}{(2)}$ & $\frac{\text { IN_IN_Unlisted }}{(3)}$ & $\frac{\text { IN_OUT }}{(4)}$ \\
\hline & & (1) & & & \\
\hline \multirow[t]{2}{*}{1} & MB_Relationship_Loan_Stock_5Y & -0.08 & -0.04 & -0.09 & -0.10 \\
\hline & & {$[-3.01]^{* * *}$} & {$[-0.89]$} & {$[-2.55]^{* *}$} & {$[-2.16]^{* *}$} \\
\hline \multirow[t]{2}{*}{2} & Long_Loans_Ratio & 0.44 & 0.75 & 0.49 & 0.46 \\
\hline & & {$[2.86] * * *$} & {$[3.17]^{* * *}$} & {$[2.81]^{* * *}$} & {$[1.75]^{*}$} \\
\hline \multirow[t]{2}{*}{3} & Pub_Bond_5Y & 0.22 & 0.23 & 0.16 & 0.09 \\
\hline & & {$[5.26] * * *$} & {$[3.88]^{* * *}$} & {$[2.88]^{* * *}$} & [1.39] \\
\hline \multirow[t]{2}{*}{4} & SEO_5Y & 0.23 & 0.20 & 0.23 & 0.23 \\
\hline & & {$[5.38]^{* * *}$} & {$[3.06]^{* * *}$} & {$[4.58]^{* * *}$} & {$[3.38]^{* * *}$} \\
\hline \multirow[t]{2}{*}{5} & In_Sales & 0.30 & 0.37 & 0.23 & 0.42 \\
\hline & & {$[26.29] * * *$} & {$[20.41]^{* * *}$} & {$[16.88]^{* * *}$} & {$[22.03] * * *$} \\
\hline \multirow[t]{2}{*}{6} & Cash_vs_TA & 0.72 & 0.40 & 0.96 & 0.50 \\
\hline & & {$[3.97]^{* * *}$} & {$[1.32]$} & {$[4.59]^{* * *}$} & {$[1.56]$} \\
\hline \multirow[t]{2}{*}{7} & Age & 0.00 & 0.00 & -0.01 & 0.00 \\
\hline & & {$[-5.47] * * *$} & {$[-1.89] *$} & {$[-8.20] * * *$} & {$[1.41]$} \\
\hline \multirow[t]{2}{*}{8} & Market_Leverge & -0.83 & -0.97 & -0.45 & -1.49 \\
\hline & & {$[-8.43] * * *$} & {$[-5.91]^{* * *}$} & {$[-3.80] * * *$} & {$[-8.76] * * *$} \\
\hline \multirow[t]{2}{*}{9} & Market_to_Book & 0.04 & -0.04 & 0.04 & -0.04 \\
\hline & & [1.09] & {$[-0.63]$} & [1.13] & {$[-0.63]$} \\
\hline \multirow[t]{2}{*}{10} & EBITDA_TA & -0.78 & -0.27 & -0.47 & -1.94 \\
\hline & & {$[-2.60] * * *$} & {$[-0.47]$} & {$[-1.36]$} & {$[-4.18] * * *$} \\
\hline \multirow[t]{2}{*}{11} & Industry_MA_Liquidity & 0.88 & 1.16 & 1.21 & 0.66 \\
\hline & & {$[1.35]$} & {$[1.13]$} & {$[1.79]^{*}$} & {$[0.58]$} \\
\hline \multirow[t]{7}{*}{12} & Herfindahl_Index & 0.63 & -0.37 & 0.69 & 0.88 \\
\hline & & {$[2.61]^{* * *}$} & {$[-0.90]$} & {$[2.39]^{* *}$} & {$[2.35]^{* *}$} \\
\hline & Year_dum & Yes & Yes & Yes & Yes \\
\hline & cons. & -4.31 & -5.63 & -3.90 & -5.96 \\
\hline & & {$[-26.41] * * *$} & {$[-21.38]^{* * *}$} & {$[-20.00] * * *$} & {$[-21.82] * * *$} \\
\hline & Pseudo R-Square & 0.14 & 0.22 & 0.10 & 0.26 \\
\hline & Obs. & 20999 & 19810 & 20139 & 19767 \\
\hline
\end{tabular}

Notes: This table presents the result of probit regressions for estimating the probability of Japanese bidders with a main banking relationship choosing an M\&A. In regression (1) the dependent variable is dummy variables which equals to 1 when an M\&A deal was done and the size of the M\&A is greater than 100 million yen, and 0 for others who did not M\&A during the fiscal year. In regression (2) the dependent variable is dummy variables which equals to 1 when an IN-IN-LISTED M\&A deal was done and the size of the IN-IN-LISTED M\&A is greater than 100 million yen, and 0 for others who did not M\&A during the fiscal year. In regression (3) the dependent variable is dummy variables which equals to 1 when an IN-IN-UNLISTED M\&A deal was done and the size of the IN-IN-UNLISTED M\&A is greater than 100 million yen, and 0 for others who did not M\&A during the fiscal year. In regression (4), the dependent variable is dummy variables which equals to 1 when an IN-OUT M\&A deal was done and the size of the IN-OUT M\&A is greater than 100 million yen, and 0 for others who did not M\&A during the fiscal year. All accounting data are taken at fiscal year-end prior to the M\&A deal. Z-statistics based on cluster-adjusted robust standard errors (Petersen, 2009). ***, **, * represent significance at 1\%, 5\%, and $1 \%$ respectively. 
Table 6: Probit results for first M\&A

\begin{tabular}{|c|c|c|c|c|c|c|c|c|c|c|c|c|c|}
\hline & & \multicolumn{3}{|c|}{ ALL } & \multicolumn{3}{|c|}{ IN_IN_Listed } & \multicolumn{3}{|c|}{ IN_IN_Unlisted } & \multicolumn{3}{|c|}{ IN_OUT } \\
\hline & & (1) & (2) & (3) & (4) & (5) & (6) & (7) & (8) & (9) & (10) & (11) & (12) \\
\hline \multirow[t]{2}{*}{1} & MB_Relationship & 0.24 & & & 0.23 & & & 0.18 & & & 0.25 & & \\
\hline & & {$[8.01]^{* * *}$} & & & {$[4.40] * * *$} & & & {$[5.09] * * *$} & & & {$[4.55]^{* * *}$} & & \\
\hline \multirow[t]{2}{*}{2} & MB_Loan_Ratio & & 0.01 & & & 0.01 & & & 0.00 & & & 0.00 & \\
\hline & & & {$[3.62] * * *$} & & & {$[2.86] * * *$} & & & {$[1.77]^{*}$} & & & {$[1.71]^{*}$} & \\
\hline \multirow[t]{2}{*}{3} & MB_Stock_Ratio & & & 0.03 & & & 0.02 & & & 0.03 & & & 0.03 \\
\hline & & & & {$[5.75] * * *$} & & & {$[2.33]^{* *}$} & & & {$[4.61]^{* * *}$} & & & {$[3.41] * * *$} \\
\hline \multirow[t]{2}{*}{4} & Long_Loans_Ratio & -0.03 & 0.00 & 0.13 & -0.01 & 0.00 & 0.14 & -0.10 & -0.06 & 0.03 & 0.19 & 0.27 & 0.36 \\
\hline & & {$[-0.23]$} & {$[0.02]$} & {$[0.87]$} & {$[-0.04]$} & {$[0.01]$} & {$[0.54]$} & {$[-0.58]$} & {$[-0.32]$} & {$[0.15]$} & {$[0.67]$} & [0.95] & [1.30] \\
\hline \multirow[t]{2}{*}{5} & Pub_Bond_5Y & 0.41 & 0.45 & 0.43 & 0.28 & 0.33 & 0.31 & 0.33 & 0.37 & 0.35 & 0.35 & 0.40 & 0.38 \\
\hline & & {$[7.86]^{* * *}$} & {$[8.75]^{* * *}$} & {$[8.34]^{* * *}$} & {$[3.55] * * *$} & {$[4.26] * * *$} & {$[3.97] * * *$} & {$[5.11] * * *$} & {$[5.61] * * *$} & {$[5.36]^{* * *}$} & {$[4.48] * * *$} & {$[5.16] * * *$} & {$[4.91] * * *$} \\
\hline \multirow[t]{2}{*}{6} & SEO_5Y & 0.26 & 0.29 & 0.32 & 0.14 & 0.17 & 0.19 & 0.27 & 0.29 & 0.32 & 0.23 & 0.26 & 0.29 \\
\hline & & {$[7.34] * * *$} & {$[8.25]^{* * *}$} & {$[8.98]^{* * * *}$} & {$[2.22]^{* *}$} & {$[2.68]^{* * *}$} & {$[3.04]^{* * *}$} & {$[6.71]^{* * *}$} & {$[7.32]^{* * *}$} & {$[7.88] * * *$} & {$[3.46]^{* * *}$} & {$[3.92]^{* * *}$} & {$[4.36]^{* * *}$} \\
\hline \multirow[t]{2}{*}{7} & In_Sales & 0.20 & 0.20 & 0.19 & 0.25 & 0.24 & 0.24 & 0.14 & 0.14 & 0.13 & 0.27 & 0.26 & 0.26 \\
\hline & & {$[19.23]^{* * *}$} & {$[19.03]^{* * *}$} & {$[18.66]^{* * * *}$} & {$[13.91]^{* * *}$} & {$[13.83]^{* * *}$} & {$[13.61] * * *$} & {$[11.23]^{* * *}$} & {$[11.03]^{* * *}$} & {$[10.81]^{* * * *}$} & {$[14.28]^{* * *}$} & {$[14.10]^{* * *}$} & {$[14.03]^{* * * *}$} \\
\hline \multirow[t]{2}{*}{8} & Cash_vs_TA & 0.59 & 0.52 & 0.51 & 0.45 & 0.37 & 0.36 & 0.55 & 0.49 & 0.49 & 0.57 & 0.47 & 0.47 \\
\hline & & {$[4.97]^{* * *}$} & {$[4.40]^{* * * *}$} & {$[4.32]^{* * * *}$} & {$[2.12]^{* *}$} & {$[1.74]^{*}$} & {$[1.71]^{*}$} & {$[4.07]^{* * *}$} & {$[3.70] * * *$} & {$[3.67]^{* * * *}$} & {$[2.59] * * *$} & {$[2.19]^{* *}$} & {$[2.18]^{* *}$} \\
\hline \multirow[t]{2}{*}{9} & Age & 0.00 & 0.00 & 0.00 & 0.00 & 0.00 & 0.00 & -0.01 & -0.01 & -0.01 & 0.00 & 0.00 & 0.00 \\
\hline & & {$[-6.52] * * *$} & {$[-5.92] * * *$} & {$[-7.06] * * *$} & {$[-1.64]$} & {$[-1.23]$} & {$[-1.74] *$} & {$[-8.17] * * *$} & {$[-7.83]^{* * *}$} & {$[-8.63]^{* * *}$} & [1.24] & [1.50] & {$[0.79]$} \\
\hline \multirow[t]{2}{*}{10} & Market_Leverge & -0.88 & -0.79 & -0.77 & -0.87 & -0.78 & -0.76 & -0.58 & -0.50 & -0.50 & -1.40 & -1.27 & -1.27 \\
\hline & & {$[-12.11] * * *$} & {$[-11.11] * * *$} & $*[-10.94]^{* * *}$ & {$[-6.83]^{* * *}$} & {$[-6.32] * * *$} & {$[-6.12] * * *$} & {$[-6.76]^{* * *}$} & {$[-6.05]^{* * *}$} & {$[-6.05]^{* * *}$} & {$[-10.32] * *$} & {$[-9.78]^{* * *}$} & {$[-9.76]^{* * * *}$} \\
\hline \multirow[t]{2}{*}{11} & Market_to_Book & 0.04 & 0.04 & 0.04 & 0.02 & 0.02 & 0.03 & 0.04 & 0.04 & 0.04 & 0.04 & 0.04 & 0.04 \\
\hline & & {$[4.32]^{* * *}$} & {$[4.41]^{* * *}$} & {$[4.75]^{* * *}$} & {$[1.27]$} & {$[1.21]$} & {$[1.51]$} & {$[3.88]^{* * *}$} & {$[3.96]^{* * *}$} & {$[4.18]^{* * *}$} & {$[2.78]^{* * *}$} & {$[2.87]^{* * *}$} & {$[3.05]^{* * *}$} \\
\hline \multirow[t]{2}{*}{12} & EBITDA_TA & -0.39 & -0.28 & -0.34 & -0.28 & 0.00 & -0.16 & -0.31 & -0.26 & -0.29 & -0.45 & -0.32 & -0.39 \\
\hline & & {$[-3.30]^{* * *}$} & {$[-2.26]^{* *}$} & {$[-2.82]^{* * *}$} & {$[-0.92]$} & {$[-0.00]$} & {$[-0.47]$} & {$[-2.56]^{* *}$} & {$[-2.03]^{* *}$} & {$[-2.33]^{* *}$} & {$[-2.00]^{* *}$} & {$[-1.18]$} & {$[-1.63]$} \\
\hline \multirow[t]{2}{*}{13} & Industry_MA_Liquidity & 0.35 & 0.42 & 0.40 & 0.29 & 0.34 & 0.33 & 1.34 & 1.40 & 1.38 & -4.05 & -4.05 & -4.01 \\
\hline & & {$[0.44]$} & {$[0.51]$} & {$[0.49]$} & {$[0.22]$} & {$[0.26]$} & {$[0.25]$} & {$[1.50]$} & {$[1.58]$} & {$[1.55]$} & {$[-1.90]^{*}$} & {$[-1.90]^{*}$} & {$[-1.89]^{*}$} \\
\hline \multirow[t]{7}{*}{14} & Herfindahl_Index & 0.72 & 0.70 & 0.74 & 0.32 & 0.28 & 0.28 & 0.92 & 0.91 & 0.95 & 0.49 & 0.43 & 0.48 \\
\hline & & {$[3.27]^{* * *}$} & {$[3.20]^{* * * *}$} & {$[3.36]^{* * * *}$} & {$[0.84]$} & {$[0.74]$} & {$[0.73]$} & {$[3.65]^{* * *}$} & {$[3.62]^{* * *}$} & {$[3.78]^{* * * *}$} & [1.22] & {$[1.06]$} & {$[1.18]$} \\
\hline & Year_dum & Yes & Yes & Yes & Yes & Yes & Yes & Yes & Yes & Yes & Yes & Yes & Yes \\
\hline & cons. & & -3.36 & -3.38 & -4.58 & -4.47 & -4.47 & -3.07 & -2.98 & -3.01 & -4.72 & -4.55 & -4.62 \\
\hline & & {$[-25.79] * * *$} & {$[-25.31] * * *$} & $*[-25.41] * * *$ & {$[-19.75]^{* *}$} & {$[-19.68]^{* *}$} & {$[-19.58]^{* * *}$} & {$[-19.51]^{* * *}$} & {$[-19.14]^{* * *}$} & $*[-19.33] * * *$ & {$[-19.32]^{* * *}$} & {$[-19.16]^{* * *}$} & {$[-19.23]^{* * *}$} \\
\hline & Pseudo R-Square & 0.11 & 0.10 & 0.10 & 0.12 & 0.11 & 0.11 & 0.09 & 0.09 & 0.09 & 0.17 & 0.17 & 0.17 \\
\hline & Obs. & 32382 & 32382 & 32382 & 31217 & 31217 & 31217 & 31777 & 31777 & 31777 & 31191 & 31191 & 31191 \\
\hline
\end{tabular}

Notes: This table presents the result of probit regressions for estimating the probability of Japanese bidders choosing an M\&A for the first time. In regressions (1), (2) and (3), the dependent variable is dummy variables which equals to 1 when an M\&A deal was done and the size of the M\&A is greater than 100 million yen, and 0 for others who did not M\&A during the fiscal year. In regressions (4), (5) and (6), the dependent variable is dummy variables which equals to 1 when an IN-IN-LISTED M\&A deal was done and the size of the IN-INLISTED M\&A is greater than 100 million yen, and 0 for others who did not M\&A during the fiscal year. In regressions (7), (8) and (9), the dependent variable is dummy variables which equals to 1 when an IN-INUNLISTED M\&A deal was done and the size of the IN-IN-UNLISTED M\&A is greater than 100 million yen, and 0 for others who did not M\&A during the fiscal year. In regressions (10), (11) and (12), the dependent variable is dummy variables which equals to 1 when an IN-OUT M\&A deal was done and the size of the IN-OUT M\&A is greater than 100 million yen, and 0 for others who did not M\&A during the fiscal year. All accounting data are taken at fiscal year-end prior to the M\&A deal. Z-statistics based on cluster-adjusted robust standard errors (Petersen, 2009). ***,**, * represent significance at $1 \%, 5 \%$, and $10 \%$ respectively. 